\title{
CÂTEVA CONSIDERAŢII PRIVIND VASELE CU TUB NEO-ENEOLITICE DESCOPERITE PE TERITORIUL ROMÂNIEI
}

LAURENŢIU GRIGORAŞ

\begin{abstract}
REZUMAT:
În campaniile din anii 2013 şi 2018 desfăşurate în situl de la Pietroasa Mică-Gruiu Dării (com. Pietroasele, jud. Buzău) au fost identificate două vase cu tub întregi, într-un nivel cu depuneri eneolitice caracterizate prin amestecul de materiale arheologice de tip Cernavoda I și Cucuteni B. Vasele de acest tip constituie descoperiri relativ rare pe teritoriul României. Unul dintre vase are două tuburi, fiind singurul de acest fel descoperit, până acum, pe teritoriul țării noastre.
\end{abstract}

Categoriile tipologice în care au fost încadrate aceste vase sunt extrem de numeroase: biberon, vase-biberon, linguri-biberon, vase cu tub, vase cu tub de scurgere, vase cu ţeavă de scurgere, vase miniaturale, vase pseudokernos, vase zise kernoi, cupe, borcane ş.a.

Funcţionalităţile prezumate ale acestor recipiente sunt, de asemenea, foarte diverse: biberoane pentru alimentarea artificială a sugarilor, recipiente pentru picurat / întins culoarea pe ceramică / suprafeţe diverse sau pentru administrarea de substanţe analgezice / curative, obiecte folosite în metalurgie, ,pipe” pentru ,fumatul” ritual, vase pentru fermentat, miniaturi aparent fără utilitate practică, vase pentru ofrande şi libaţii, vase cu valenţe cultice ş.a.

În contextul acestei diversităţi tipologice şi funcţionale, precum şi al descoperirilor recente de la Gruiu Dării, am considerat utilă formularea câtorva consideraţii referitoare la caracteristicile acestui tip de vase.

\section{Abstract: Some considerations Regarding the vessels With tUbe from the Neolithic AND THE CHALCOLITHIC DISCOVERED ON THE TERRITORY OF ROMANIA}

During the 2013 and 2018 seasons, carried out at the site of Pietroasa Mică-Gruiu Dării (Pietroasele Commune, Buzău County) two complete vessels with tube were discovered in a layer with Chalcolithic depositions, characterized by a mixture of Cernavoda I and Cucuteni B archaeological materials. Such vessels are relatively rare discoveries on the territory of Romania. One of these vessels has two tubes, being the only one of this kind discovered so far on the Romanian territory.

The typological categories in which these vessels were gruped are extremely numerous: baby bottle, baby feeding vessels, baby nursing spoons, vessels with tube, vessels with drain-tube, vessels with drain-pipe, miniature vessels, pseudo-kernos vessels, so-called kernoi vessels, cups, jars etc.

The presumed functionalities of these artefacts are also very diverse: baby bottles for the artificial feeding of infants, recipients for dripping / spreading the colour on ceramic / various surfaces or for the administration of analgesic / curative substances, objects used in metallurgy, "pipes" for ritual "smoking", vessels for fermentation, miniatures apparently without practical utility, offerings and libations pots, vessels with cultic connotations etc.

In the context of this typological and functional diversity, as well as of the recent discoveries from Gruiu Dării, we thought it is useful to propose some considerations regarding the characteristics of this type of vessels.

CUVINTE CHEIE: neo-eneolitic, biberon, vase-biberon, vase cu tub, Pietroasa Mică - Gruiu Dării.

KeYwords: Neo-eneolithic, baby bottle, baby feeding vessels, vessels with tube, Pietroasa Mică - Gruiu Dării. 


\section{Introducere}

Descoperirea recentă, în situl arheologic de la Pietroasa Mică-Gruiu Dării, a două vase cu tub întregi ${ }^{1}$, precum şi identificarea, pe teritoriul României, a altor recipiente asemănătoare, ne-au determinat să reluăm dezbaterea, de altfel nu lipsită de controverse, circumscrisă acestei categorii „speciale” a materialului ceramic neo-eneolitic.

$\mathrm{Cu}$ excepţia datelor referitoare la piesele menţionate în studiile mai multor autori, tratate într-o manieră sintetizată, unitară şi comparativă, am încercat să centralizăm şi să prezentăm descoperirile de acest tip, pe cât posibil în ordinea cronologică a descoperirii şi mai ales a publicării lor. Am considerat acest demers, oarecum de tip ,istoriografic”, ca fiind cel mai adecvat pentru analizarea şi evaluarea opiniilor formulate de-a lungul timpului, prin plasarea acestora în contextul descoperirilor şi acumulărilor bibliografice existente la momentul respectiv.

Deşi, la o primă vedere, poate părea un demers de trecere în revistă a tuturor descoperirilor de acest tip, studiul nostru nu are şi nici nu poate avea, din motive obiective pe care le vom enunţa şi detalia, caracterul unei abordări exhaustive a tematicii propuse.

Preluarea, din studii mai vechi, a unor ilustraţii (fotografii şi desene) cu piese publicate fără scară şi la care nu am avut acces pentru cercetare, ne-au determinat să consemnăm, ori de câte ori acestea erau menţionate, dimensiunile vaselor sau fragmentelor de vase prezentate. De asemenea, am considerat că prezentarea dimensiunilor este foarte importantă din perspectiva, adecvat argumentată, a relevanţei acestora pentru indicarea posibilelor funcţionalităţi ale obiectelor respective. Acelaşi motiv, alături de calitatea precară a unora dintre ilustraţiile preluate sau, în unele situaţii, chiar lipsa acestora, ne-au determinat să prezentăm descrieri cât mai detaliate ale vaselor în cauză. Am considerat utilă această abordare prin prisma faptului că informațiile referitoare la dimensiunile vaselor, capacitatea de stocare, poziţia, forma şi dimensiunile tubului sunt considerate, de majoritatea specialiştilor, ca fiind elemente extrem de importante pentru stabilirea utilităţii acestora.

Comparaţiile cu piese asemănătoare aparţinând altor epoci istorice au avut ca unic scop documentarea diferitelor etape ale dezbaterilor referitoare la funcţionalitatea acestei categorii de vase.

\section{Terminologie: opinii și considerații}

De-a lungul timpului, arheologii care au abordat problematica acestui tip de vase au folosit pentru identificarea acestora terminologii diverse (biberon ${ }^{2}$, vase-biberon ${ }^{3}$, vase cu tub ${ }^{4}$, vase cu tub de scurgere ${ }^{5}$, vase cu ,ţeavă” de scurgere ${ }^{6}$ ş.a.).

E. Ruttkay a inclus aceste descoperiri în categoria mai largă a aşa-numitelor pseudo-kernos (vase cu brațe, vase cu tub, vase mixte, vase de fermentare, vaze de flori, suporturi pentru lumânări etc. $)^{7}$. O abordare mai nuanţată a fost susţinută de D. Boghian, care a inclus recipientele cu tub în categoria vaselor ,zise kernoi”, despre care consideră că au avut „funcţionalități diverse, rituale şi practice, poate combinate, încă neprecizate”».

Tuburi ataşate unor forme ceramice se regăsesc şi în cazul vaselor cu „braţe-tub”, considerate ca fiind înfăţişări ale corpului uman şi incluse de R. Andreescu într-o clasificare a reprezentărilor cu atribute antropomorfe ${ }^{9}$. Aceste tipuri de vase ,au corpul mai mult sau mai puţin bombat, deasupra lui fiind modelat un cap uman" 10 şi au fost descoperite într-un context arheologic Gumelniţa A2-B1. Comparând vasele cu braţe-tub cu cele cu braţe pline, neperforate, autorul consideră că cele două tipuri de reprezentări antropomorfe au funcţionalităţi diferite, existând posibilitatea „ca ele să reprezinte teme cultice asemănătoare”"11.

Mai mult decât atât, ca şi cum această diversitate terminologică nu ar fi fost îndeajuns de cuprinzătoare, mulţi arheologi români au publicat piesele respective fără nici o precizare referitoare la tipologia și utilitatea acestora sau le-au încadrat în categorii mai largi ale ceramicii epocii respective, cum ar fi, de exemplu, cupele ${ }^{12}$, borcanele ${ }^{13}$, castroanele, oalele ${ }^{14}$ sau vasele miniaturale ${ }^{15}$.

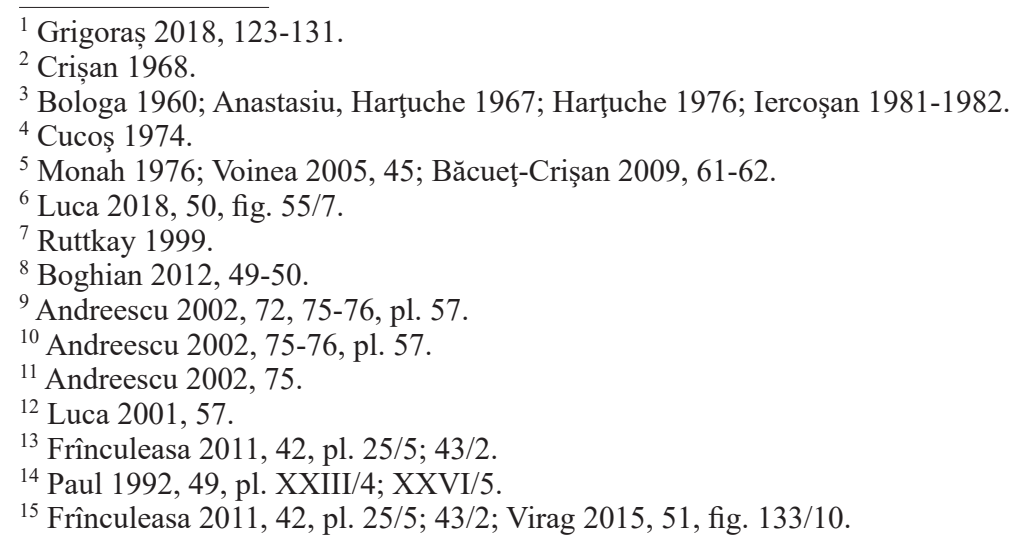


Considerăm că denumirea de vase cu tub, consecvent utilizată doar de Şt. Cucoş ${ }^{16}$, constituie terminologia cea mai adecvată de identificare şi încadrare a acestei categorii ceramice. Această denumire ar putea fi percepută, la o primă vedere şi prin comparaţie cu altele, aparent mai „explicite”, ca fiind o sintagmă „,neutră”, pur descriptivă şi poate mai puţin ,sugestivă” în privinţa indicării unei / unor funcţionalităţi precise. Apreciem această terminologie ca fiind mult mai „,eschisă” şi adaptată pentru integrarea diversităţii de forme şi funcţionalităţi prezumate ale vaselor respective. Utilizarea acestei denumiri ar asigura un cadru suficient de larg şi, în acelaşi timp, bine individualizat, de natură să permită acumulări de descoperiri asemănătoare, fără nevoia ajustărilor repetate de terminologie.

Dificultăţile întâmpinate în identificarea multora dintre vasele cu tub folosite pentru documentarea prezentului studiu s-au datorat, în mare măsură, încadrării imprecise sau neclare a acestora în categorii extrem de diverse sau foarte largi ale ceramicii neo-eneolitice. Este foarte probabil ca lipsa de consistenţă şi uniformitate manifestată în încadrarea acestor recipiente să nu ne fi permis identificarea mai multor vase de acest tip.

Considerăm că vasele cu tub prezintă toate caracteristicile necesare pentru a le individualiza şi a argumenta constituirea acestora într-o categorie distinctă a materialului ceramic neo-eneolitic.

\section{Istoricul descoperirilor și dezbaterilor referitoare la funcționalitate}

Primele ipoteze referitoare la această categorie de vase au fost formulate pe baza analogiilor cu recipientele din sticlă cu tub analizate de V. Bologa ${ }^{17}$ şi considerate de acesta gutti (biberoane), utilizate în perioadă romană la hrănirea sugarilor. Autorul preia astfel presupunerea ${ }^{18}$ potrivit căreia alimentarea copiilor din astfel de vase necesita înfăşurarea ciocului sau tubului aferent, ,într-o cîrpă subţire curată, sau chiar într-un tub de piele argăsită de mamelon de capră" ${ }^{19}$. V. Bologa menţiona, într-o notă a studiului său, că nu erau cunoscute, până la acea dată, vase-biberon din lut ars descoperite pe teritoriul ţării noastre ${ }^{20}$. Pornindu-se de la presupusa funcţionalitate dedusă din forma acestor vase şi în lipsa accesului la cunoaşterea unor piese asemănătoare din alte epoci istorice, termenul de vas-biberon a fost preluat şi utilizat, de unii cercetători, pentru descoperiri ulterioare prezumate a fi similare.

La şapte ani de la apariţia studiului lui V. Bologa, în anul 1967, F. Anastasiu şi N. Harţuche publicau primul vas cu tub întreg (Pl. I/1-6), descoperit în urma unui sondaj efectuat în 1958 la Rîmnicelu, punctul La pochină (jud. Brăila) ${ }^{21}$. Vasul are următoarele dimensiuni: $H=10 \mathrm{~cm}$; Dgură $=6,4 \mathrm{~cm}$; Dfund $=8 \mathrm{~cm}$; dimensiuni tub: lungimea pe orificiul longitudinal $=3 \mathrm{~cm}$; Dtub $=2,4 \mathrm{~cm}$; Dorificiu $=0,8 \mathrm{~cm}$. Iniţial, autorii atribuie această descoperire culturii Cernavoda I, pentru ca ulterior N. Harţuche să reevalueze datarea acestui vas „la sfârşitul eneoliticului, probabil într-o etapă Prehorodiştea"22.

În anul 1968 E. Crişan publică un „biberon” hallstattian (Pl. II/1-3) descoperit la Stupini (jud. Bistriţa-Năsăud) ${ }^{23}$, considerându-l asemănător ca formă şi rol funcţional cu vasul de la Rîmnicelu. Vasul are următoarele dimensiuni: H = 7,2 cm; Dmax. =6,8 cm; Dgură = 5,7 cm; Dfund = 3,5 cm; grosimea pereţilor = 0,6 cm; capacitatea $=150 \mathrm{~g} . P \mathrm{e}$ baza analogiilor cu descoperiri din Egipt, Fenicia şi Babilon, dar şi din Europa (Ungaria şi Germania) ${ }^{24}$, şi pornind de la datarea iniţială a recipientului de la Rîmnicelu, E. Crişan consideră cele două vase ca fiind „,biberoane” şi concluzionează afirmând că ,cele două biberoane de lut descoperite pe teritoriul țării noastre se dovedesc a fi printre cele mai vechi din Europa, atestînd existenţa alimentării artificiale a sugarilor la noi încă de la începutul epocii bronzului" 25. Aceeaşi concluzie este împărtăşită de N. Harţuche, care - analizând comparativ vasul de la Rîmnicelu cu cele de la Stupini şi Ghelăieşti-Nedeia (jud. Neamţ) - consideră că „,putem afirma cu certitudine că avem de-a face cu un vas biberon"26.

Într-un amplu articol dedicat studierii eneoliticului final dintre Dunăre şi Carpaţi, publicat de P. Roman în anul 1971, sunt ilustrate două fragmente de vase cu tub descoperite la Pecica-Şanţul Mare (Pl. II/4) şi Ostrovul Corbului (Pl. II/5 $)^{27}$. Vasul cu tub de la Ostrovul Corbului a fost inclus de I. Sălceanu în categoria vaselor cu ,,jgheab de scurgere"28

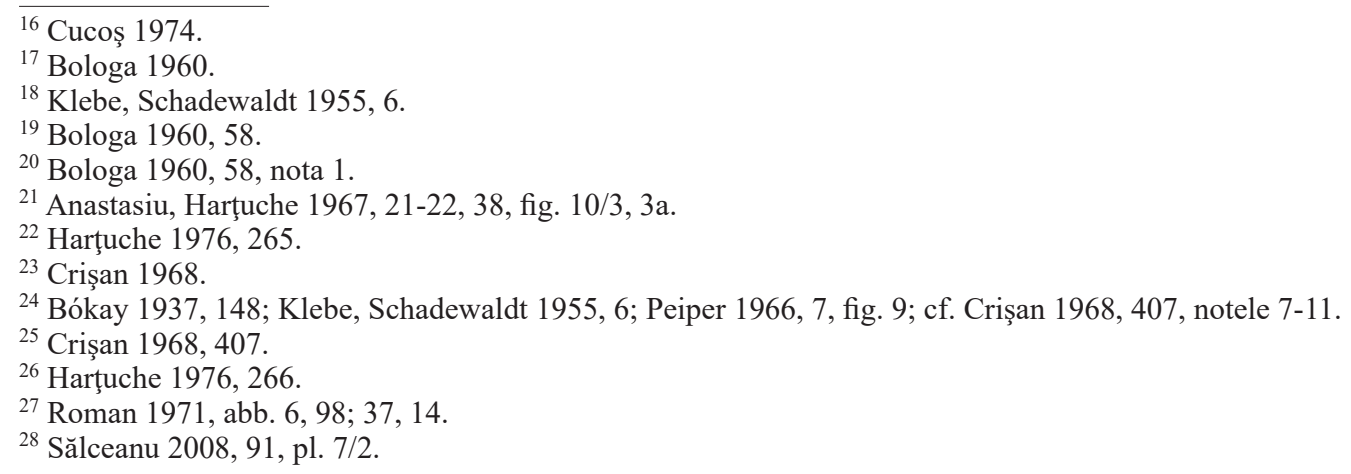


şi atribuite orizontului cultural de tip Sălcuţa IV - Herculane II-III. Bazându-ne chiar pe ilustraţia prezentată de I. Sălceanu pentru exemplificarea acestei categorii (Pl. II/6), considerăm că tubul vaselor menţionate de P. Roman diferă, în mod evident, ca formă şi mod de realizare, de „,ciocul” recipientelor cu ,jgheab”. Credem că posibilele similarităţi de funcţionalitate nu sunt suficiente pentru a argumenta includerea, fără nici o distincţie, a vaselor cu tub şi a celor cu ,jgheab” într-o singură categorie tipologică, individualizată prin indicarea ,dispozitivului” de scurgere. Apreciem că această diferenţiere este utilă şi din perspectiva analizării opiniilor referitoare la posibila „filiaţie” a vaselor cu tub din cele „cu cioc de turnare şi perete perforat” ${ }^{29}$. Prezenţa simultană, în timp şi spaţiu, a celor două tipuri de recipiente, susţinută inclusiv prin piesele prezentate de I. Sălceanu ${ }^{30}$, exclude probabilitatea derivării vaselor cu tub din cele cu ,cioc” sau ,jgheb”.

Într-un studiu dedicat vaselor neo-eneolitice cu tub şi semnificaţiei acestora ${ }^{31}$, Şt. Cucoş prezenta un astfel de recipient (Pl. III/1-4), descoperit întreg, în anul 1971, în aşezarea cucuteniană de la Ghelăieşti-Nedeia (jud. Neamţ). Vasul are următoarele dimensiuni: $\mathrm{H}=5,4 \mathrm{~cm}$; Dgură $=3,8 \mathrm{~cm}$; Dmax. $=5,7 \mathrm{~cm}$; lungimea tubului pe orificiul longitudinal = 2,2 cm. Acesta a fost găsit într-o locuinţă atribuită etapei Cucuteni A2, fiind - potrivit autorului „al doilea de acest fel din faza Cucuteni A2, un exemplar similar fiind descoperit de colegul Dan Monah [...] în aşezarea neolitică Cetăţuia-Vermeşti (jud. Bacău)"32. Şt. Cucoş consideră că vasul de la Ghelăieşti-Nedeia are, din punct de vedere tipologic, analogii cu o piesă fragmentară (P1. III/5-7) descoperită la Tîrpeşti (jud. Neamţ) $)^{33}$ şi atribuită culturii ceramicii liniare ${ }^{34}$, cu un vas miniatural de la Şipeniţ, Ucraina (faza Cucuteni B) (35 $^{35}$ precum şi cu vasele de la Rîmnicelu şi Stupini, acesta din urmă fiind considerat mult mai apropiat ca formă şi dimensiuni de piesa de la Ghelăieşti.

Raportându-se la constatările formulate pe baza cercetării civilizaţiilor mesopotamiene, Şt. Cucoş respinge posibilitatea utilizării pediatrice a vaselor cu tub, argumentând opinia folosirii rituale a acestora, ,fie în practica libaţiilor, fie depuse în morminte" ${ }^{36}$. Deşi le consideră ca fiind puţin probabile, autorul menţionează totuşi şi alte posibile utilizări ale acestor recipiente: ,instrumente pentru picurat „,medicamente” sau prin prelungirea tubului cu o trestie puteau fi folosite la arderea unor ierburi şi la „fumatul ritual” practică cunoscută la populaţiile primitive actuale" ${ }^{\prime 37}$. Raritatea descoperirilor de acest fel este interpretată de autor ca un contraargument la utilizarea ca „biberoane” a acestor vase, considerându-se că pentru a se susţine o asemenea funcţionalitate ,,ar fi trebuit să fie găsite cîteva exemplare de acest fel în fiecare aşezare cucuteniană cercetată şi chiar în aşezările culturilor contemporane”38. Afirmaţia potrivit căreia ,vasele neo-eneolitice cu tub, cu excepţia fragmentului de la Tîrpeşti aparţinînd ceramicii liniare, sînt cunoscute numai în aria culturii Cucuteni"’39 reflectă, în mod evident, o etapă tranzitorie a cercetărilor şi posibilităţilor de documentare a unor descoperiri asemănătoare.

D. Monah ${ }^{40}$ publică un „vas miniatural cu tub” (Pl. IV/1-7) descoperit într-o locuinţă atribuită etapei Cucuteni A2, identificată în urma unui sondaj de salvare efectuat în anul 1971 în aşezarea neolitică de la Vermeşti-Cetăţuie (Vermeşti-Comăneşti). Au fost consemnate următoarele dimensiuni: $\mathrm{H}=4,9 \mathrm{~cm}$; Dfund $=5 \mathrm{~cm}$; Ltub $=3 \mathrm{~cm}$; Dgură $=5,2 \mathrm{~cm}^{41}$. Făcând o centralizare a pieselor asemănătoare publicate până la apariţia studiului său, autorul constată că primele menţionări ale unor fragmente de vase cu tub sau cioc descoperite în aşezări preistorice din România sunt destul de vechi şi provin din aşezarea de la Turdaş (Pl. V/1-12) ${ }^{42}$. D. Monah nu consideră „,vasele cu tub de scurgere" ca fiind „derivate" ${ }^{43}$ din recipientele cu cioc, afirmând că acestea reprezintă două forme ceramice ,înrudite", constatare argumentată prin existenţa paralelă a acestora şi probabilele similarităţi de funcţionalitate ${ }^{44}$.

Pe lângă unele din recipientele deja amintite în acest studiu, autorul citează şi alte informaţii referitoare la vase cu tub, întregi sau fragmentare, descoperite în aşezări de pe teritoriul ţării noastre şi care au fost atribuite mai multor culturi neo-eneolitice: un tub (Pl. III/5-7) puternic curbat, cu lungimea de 10,4 cm şi diametrul de 3,6 cm,

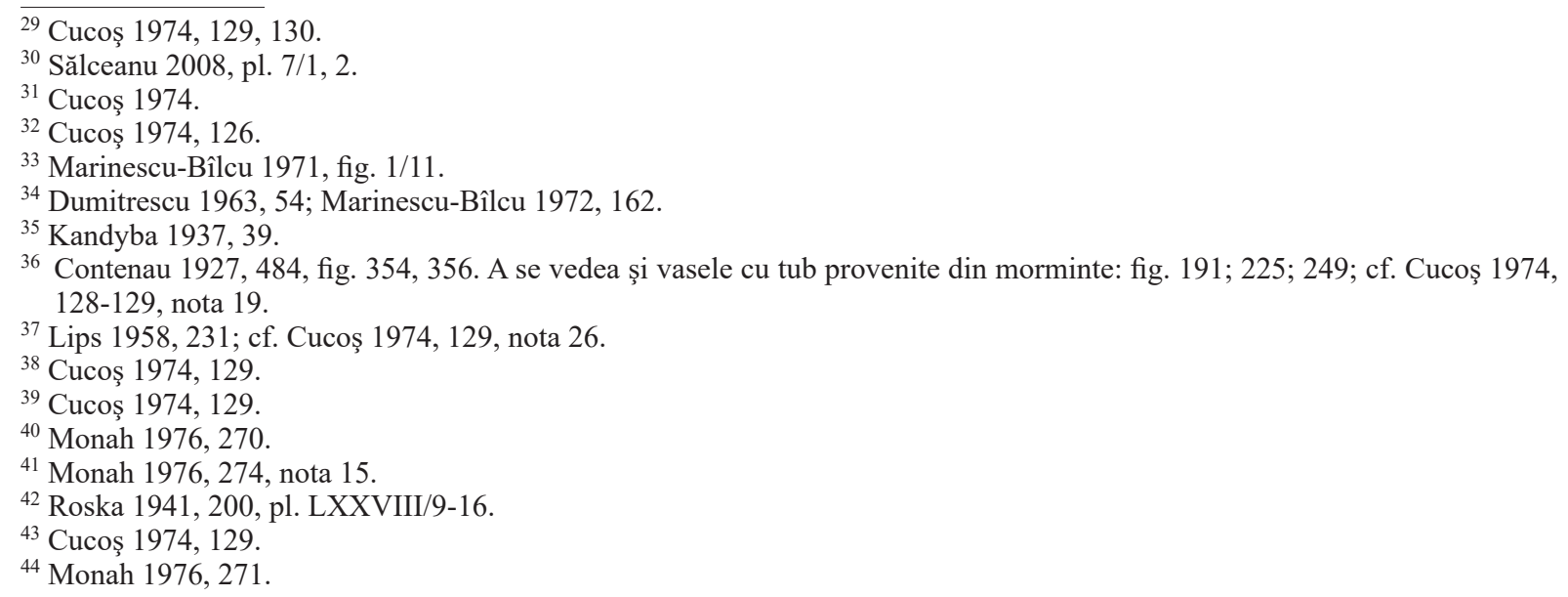


descoperit în aşezarea de la Tîrpeşti (jud. Neamţ) şi atribuit culturii ceramicii liniare ${ }^{45}$; vasul miniatural cu tub $(\mathrm{H}=$ $2,3 \mathrm{~cm}$ ) găsit în aşezarea Precucuteni I de la Traian-Dealul Viei ${ }^{46}$; un fragment din partea superioară a unui vas cu buza evazată, prevăzut cu un tub masiv şi arcuit (Pl. VI/5, 6), identificat în aşezarea Precucuteni II de la Ghigoeşti (jud. Neamţ) şi considerat ca putând proveni de la un „vas dublu”47; vasul fragmentar (Pl. VI/1, 2) de la Ghelăieşti, provenit dintr-o locuinţă atribuită etapei Cucuteni B1 (Ltub = 3,5 cm; Dtub la bază $=3,2 \mathrm{~cm}$; Dorificiu scurgere = $1,4 \mathrm{~cm}$; Dgură $=8 \mathrm{~cm}$; înălţimea probabilă $=8-10 \mathrm{~cm})^{48}$; un fragment dintr-un vas cu cioc găsit în acelaşi sit (Pl. $\mathrm{VI} / 3)$; un tub (Pl. VI/4) cu diametrul orificiului de $2 \mathrm{~cm}$, probabil parte a unui vas de dimensiuni mari descoperit în situl cucutenian de la Văleni - Piatra-Neamţ̧ ${ }^{49}$ şi un vas cu tub datat în faza Cucuteni A, descoperit de Şt. Cucoş în aşezarea de la Piatra Şoimului (fostă Calu) ${ }^{50}$.

Apreciind descoperirea de la Tîrpeşti ca fiind cea mai veche din neoliticul românesc, D. Monah consemnează frecvenţa acestui tip de vase în aşezările contemporane din Europa Centrală $\breve{a s}^{51}$ şi afirmă că ,,apariţia acestei forme în mediul precucutenian ar putea fi de tradiţie liniar-ceramică" ${ }^{\prime \prime 2}$. Un astfel de vas, atribuit culturii ceramicii liniare, a fost descoperit la Steigra (Germania) şi a fost datat între $5500-4800 \mathrm{BC}^{53}$, fără a se preciza dacă a fost utilizat pentru hrănirea sugarilor.

D. Monah consideră că dimensiunile variabile ale acestor vase (foarte mari sau foarte mici), poziţia, forma şi dimensiunile tubului de scurgere, interiorul poros, maniera neglijentă de modelare a acestor recipiente şi „,caracterul rural” al aşezărilor în care au fost descoperite sunt argumente care pledează împotriva utilizării ca „,biberoane” a pieselor respective. Menţionând prezenţa vaselor cu tub în aşezări şi necropole aparţinând unor nivele neolitice timpurii de la Susa şi din Mesopotamia ${ }^{54}$, autorul consideră că „nu există nici o raţiune pentru depunerea unor vase-biberon în mormintele adulţilor. Prezenţa unor vase de libaţii este explicabilă's5. El concluzionează afirmând „,ă vasele cu tub neo-eneolitice din Europa răsăriteană pot fi considerate, pe baza argumentelor de mai sus, vase pentru libaţie, prin analogie cu vasele şi ritualurile din Orientul Apropiat"s56.

N. Iercoşan ${ }^{57}$ publică un „vas-biberon eneolitic” (Pl. VII/1, 2) descoperit de cercetătorul J. Németi în apropierea satului Ciumeşti, punctul Gropi de silozuri (com. Sanislău, jud. Satu Mare). Vasul, păstrat întreg, este descris de autor ca având o formă semisferică şi sunt consemnate următoarele dimensiuni: $\mathrm{H}=61 \mathrm{~mm}$; Dgură $=86 \mathrm{~mm}$; Dbază $=54 \mathrm{~mm}$; Dmax. $=92 \mathrm{~mm}$; grosimea pereţilor $=6 \mathrm{~mm}$; greutate $=180$ gr; capacitate $=185 \mathrm{ml}$. Tubul, cu formă cilindrică, este dispus în partea superioară a vasului, aproximativ pe linia diametrului maxim şi are lungimea de $16 \mathrm{~mm}$, diametrul interior de $3 \mathrm{~mm}$, iar cel exterior de $9 \mathrm{~mm}$ la vârf şi de $12 \mathrm{~mm}$ la bază. N. Iercoşan apreciază că acest vas ,se poate data în eneoliticul timpuriu şi aparţine culturii Bodrogkeresztúr, ultima perioadă a complexului cultural Tisa" ${ }^{\$ 8}$. Această încadrare cronologică va fi contrazisă ulterior de J. Németi, potrivit căruia „cultura Bodrogkeresztúr se încadrează în eneoliticul dezvoltat şi nu face parte din complexul Tisa, care îşi încheie evoluţia în faza sa finală, contemporană cu cultura Lengyel târzie" ${ }^{\prime 59}$. Încadrarea cronologică eronată a vasului cu tub descoperit la Ciumeşti a fost semnalată şi de C. Virag ${ }^{60}$. N. Iercoşan remarcă faptul că recipientul cu tub de la Ciumeşti este al patrulea „vas-biberon” descoperit întreg pe teritoriul României, alături de vasele deja menţionate de la Rîmnicelu (jud. Brăila), Ghelăiești-Nedeia (jud. Neamţ) şi Vermeşti-Cetăţuie (jud. Bacău). Autorul subliniază importanța acestei descoperiri din perspectiva extinderii spre nord-vestul ţării a ariei cunoscute de răspândire a acestui tip ceramic, menţionând în acest context şi un fragment de „vas-biberon” eneolitic din Transilvania, găsit în context Ariuşd ${ }^{61}$.

Tot din apropierea satului Ciumeşti, din punctul La Silozuri / Fântâna Păşunii, provine şi un fragment dintr-un „vas-biberon” (Pl. VII/3), identificat de J. Németi în cadrul colecţiilor „Kovács” şi menţionat de acesta în studiile

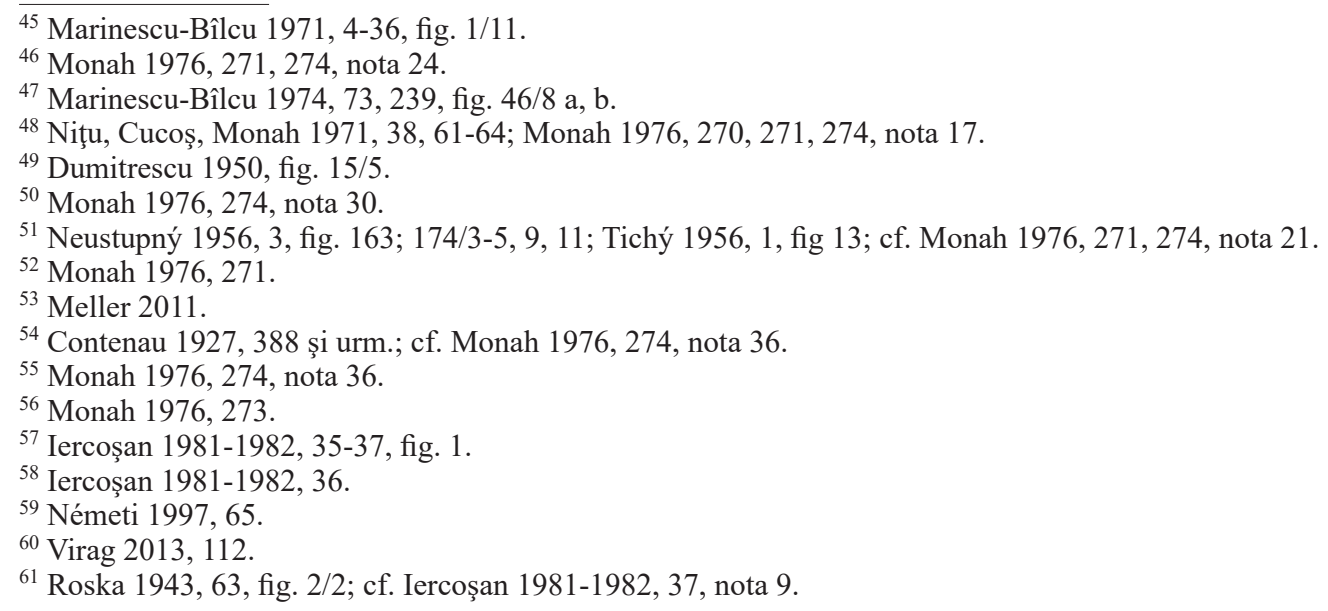


publicate în anii $1997^{62}$ şi $1999^{63}$. Vasul, descris de autor ca având forma unui borcănaş cu gura largă, are tubul rupt şi se presupune că a fost utilizat la alimentarea unui copil sau eventual a unui animal. Vasul are următoarele dimensiuni: Dgură $=6,5 \mathrm{~cm} ; \mathrm{H}=4,5 \mathrm{~cm}$; Dfund $=3,3 \mathrm{~cm}$; lungimea probabilă a tubului $=2,5 \mathrm{~cm}$. J. Németi consideră acest fragment de vas ca fiind foarte asemănător cu vasul cu tub publicat de N. Iercoşan şi datează cele două piese în eneoliticul târziu, cultura Bodrogkeresztúr. Acest vas cu tub, fragmentar, este menţionat şi de C. Virag, într-un studiu dedicat analizei materialelor ceramice eneolitice din colecţia Kovács ${ }^{64}$.

Gavril Luca publică un vas cu tub ${ }^{65}$ (Pl. VII/4) descoperit la Drăguşeni-Fălticeni (jud. Suceava), pe care-1 atribuie etapei B1 a culturii Cucuteni. Vasul are dimensiuni reduse $(H=4,8 \mathrm{~cm}$; Dmax. $=6,5 \mathrm{~cm}$; Dgură =2,5-2,7 cm) şi este descris ca având fund semisferic şi „formă sferoidală, uşor ovalizată pe direcţia longitudinală a tubului”"66. Tubul, păstrat parţial, are formă tronconică, este dispus în partea superioară a vasului şi a fost „tras” din pasta acestuia, fiind perforat dinspre exterior spre interior. Raportându-se la forma şi dimensiunile vasului de la DrăguşeniFălticeni, autorul consideră că acesta are strânse analogii cu vasele cu tub de la Traian-Dealul Viei (Precucuteni I) şi mai ales cu cel de la Ghelăieşti-Nedeia (Cucuteni A2). În acelaşi studiu este menţionat un fragment de tub de vas descoperit de I. Untaru, în anul 1972, în aşezarea Cucuteni B de la Tîrgu Neamţ-Dealul Pometea. Tubul, de formă tronconică, are 2,5 cm lungime, diametrul orificiului de $0,8 \mathrm{~cm}$ la vârf şi $1,2 \mathrm{~cm}$ la bază.

Reamintind cele mai vehiculate ipoteze emise până atunci cu privire la modul de utilizare al acestor vase, G. Luca apreciază că folosirea lor în cadrul activităţilor cu caracter ritual (libaţii) a fost mai convingător fundamentată decât atribuirea unui caracter pediatric descoperirilor în cauză. Această opinie este argumentată prin deja binecunoscuta şi frecvent menţionata constatare a rarităţii descoperirilor de acest fel. G. Luca explică frecvenţa redusă a acestor vase prin posibilitatea ca ele să fi „,constituit numai apanajul unor şefi spirituali ai comunităţilor gentilice" ${ }^{97}$. Autorul nu exclude însă posibilitatea ca vasele cu tub să fi avut totuşi şi o utilizare practică: manipularea unor lichide preţioase în practica medico-rituală sau pipete pentru întinderea unor substanţe necesare realizării tatuajelor.

În anul 1987, D. Boghian şi C. Mihai publică un vas cu tub de scurgere ${ }^{68}$ descoperit cu ocazia cercetărilor arheologice desfăşurate în perioada 1971-1973 în aşezarea cucuteniană de la Buznea-Silişte (Târgu Frumos - jud. Iaşi). Vasul (Pl. VII/5) făcea parte din inventarul unui complex arheologic interpretat de autori ca reprezentând o locuinţă de cult datată în etapa Cucuteni B1. Din desenul publicat de autori reiese că vasul $(\mathrm{H}=5 \mathrm{~cm})$ are corp bitronconic, rotunjit în zona diametrului maxim, fund plat, iar tubul pare să fi fost rupt din vechime. Acelaşi vas este menţionat şi de C.-M. Mantu-Lazarovici, alături de alte piese cărora li se atribuie o „semnificaţie cultuală”, ca „recipiente protectoare” ale unui conţinut preţios ${ }^{69}$.

Un vas cucutenian (Pl. VII/6) descoperit la Răuceşti-Munteni, asemănător ca formă şi dimensiuni cu cel de la Buznea-Silişte, a fost publicat în anul 1992 de Gh. Dumitroia ${ }^{70}$. Vasul are înălţimea de 4,8 cm, fund plat, corp cvasi globular, iar tubul, tras din pastă, este poziţionat aproximativ perpendicular pe linia diametrului maxim.

În monografia culturii Petreşti, publicată de I. Paul în 1992, autorul menţionează descoperirea, în aşezările de la Păuca-Homm (Pl. VIII/1) şi Ghirbom (Pl. VIII/2), a câtorva fragmente de ,castroane şi oale cu tub” pe care le consideră „,moştenite, ca tip de vas, din cultura Turdaş"71.

În analiza ceramicii complexului cultural Gumelniţa-Karanovo VI, V. Voinea ${ }^{72}$ include „vasele cu tub de scurgere” (P1. VIII/3-6) în cadrul unei categorii de ,,piese ceramice deosebite”, ce cuprinde obiecte care nu au putut fi încadrate tipologic în nici unul din tipurile descrise în lucrarea de sinteză publicată în anul 2005. Acest tip ceramic este considerat ca având „o largă răspândire în timp şi spaţiu, interpretările privind utilitatea lor fiind dintre cele mai variate" 73 . Este menţionat faptul că vasele cu tub reprezintă descoperiri întâlnite ,în toate regiunile complexului Gumelniţa-Karanovo VI, atât în faza timpurie (Lişcoteanca [...] ), cât şi în fazele Gumelniţa A2 şi B1 (Drama [...]; Cuneşti [...]; Căscioarele-L.3 [...] )" "74. Dacă în privinţa vaselor cu tub miniaturale, V. Voinea consideră plauzibilă ipoteza utilizării acestora în scopuri cultice, pentru vasele cu dimensiuni medii, precum cele descoperite

\footnotetext{
${ }^{62}$ Németi 1997, 64-65, fig. 3/1-3.

${ }^{63}$ Németi 1999, 52.

${ }^{64}$ Virag 2013, 112.

${ }^{65}$ Luca 1984-1985, 394, fig. 1.

${ }^{66}$ Luca 1984-1985, 393.

${ }^{67}$ Luca 1984-1985, 395.

${ }^{68}$ Boghian, Mihai 1987, 314, 322, fig. 6/1.

${ }^{69}$ Mantu-Lazarovici 2004, 54.

${ }^{70}$ Dumitroaia 1992, 100, 105, fig. 4/2.

${ }^{71}$ Paul 1992, 49, pl. XXIII/4; XXVI/5.

${ }^{72}$ Voinea 2005, 45, pl. 45/1-3; 89/3.

${ }^{73}$ Voinea 2005, 45, nota 34.

${ }^{74}$ Voinea 2005, 45.
} 
la Căscioarele şi în regiunea Varna (vas cu patru tuburi), autoarea nu exclude posibilitatea ca acestea să fi fost folosite în ,activităţi casnice”.

În anul 2007 a fost descoperit în aşezarea de la Mălăieştii de Jos (jud. Prahova) un fragment dintr-un vas cu tub (P1. IX/1), într-o locuinţă (L.5) atribuită aspectului cultural Stoicani-Aldeni ${ }^{75}$.

În situl neo-eneolitic de la Seciu-La Pompieri (jud. Prahova) a fost descoperit, în anul 2009, un vas tronconic (Pl. IX/2, 3), cu corpul întreg şi tubul spart din vechime ${ }^{76}$. Acesta a fost atribuit culturii Gumelniţa, fiind încadrat de A. Frînculeasa, după dimensiune, în categoria vaselor miniaturale, iar din punct de vedere tipologic, în cea a vaselor „de forme diverse prevăzute cu tuburi de scurgere sau poate de ataşare a unui mâner din lemn (tigăi, borcane, polonice)"'77.

S. Luca, în două volume publicate în anii 2001 şi 2018, referitoare la rezultatele cercetărilor din siturile neolitice de pe Valea Mureşului (campaniile 1992-1995 şi 1996-1998), menţionează descoperirea, în aşezarea de la TurdaşLuncă, a unor vase „cu ţeavă de scurgere” ${ }^{78}$, atribuite de autor fazei II a culturii Turdaş şi incluse în categoria „,străchinilor simple, plate" 79 .

În anul 1996 a fost descoperit, într-o locuinţă vinčiană timpurie din situl de la Limba-Oarda de Jos - Şesu Orzii (jud. Alba), un fragment de vas cu tub de scurgere (Pl. IX/4, 5), decorat cu incizii late, dispuse oblic. M. Ciută prezintă acest „,vas ceramic cu tub de scurgere (vas biberon)” într-un studiu publicat în anul 2013, cu menţiunea că fragmente de vase similare au fost descoperite ,în cadrul depunerilor vinčiene timpurii, dar şi mai târzii, din Banat şi din Transilvania" 80 . Prezenţa, pe acest fragment, a decorului incizat, constituie o raritate pentru vasele cu tub atribuite perioadei neo-eneolitice.

C. Pătroi menţionează, într-un studiu publicat în anul 2013, un vas cu „tub de scurgere” descoperit în aşezarea atribuită culturii Sălcuţa de la Drăgăneşti-Olt - Corboaica. Subliniind caracteristicile tipic gumelniţene ale materialelor ceramice descoperite în situl respectiv, autorul consemnează că vasul cu tub de la Drăgăneşti-Olt, ,ce îl întâlnim în fazele I, II c de la Sălcuţa, faza III de la Ostrovul Corbului şi Almăjel este întâlnit în toate regiunile Gumelniţa / Karanovo VI pe întreaga perioadă de evoluţie" ${ }^{81}$.

În lucrarea publicată în anul 2015, C. Virag prezintă un ,vas miniatural” $(H=3 \mathrm{~cm}$; Dgură = $5 \mathrm{~cm}$; Dfund = $2 \mathrm{~cm})$, fragmentar, cu tub de scurgere (P1. IX/6, 7) ${ }^{82}$. Materialele arheologice descoperite la Halmeu au fost atribuite ,fazei târzii a grupului Pişcolţ, la un orizont Iclod Ib - I/II" "83. Remarcând diversitatea terminologică existentă pentru încadrarea acestui tip de vase (vase de tip biberon sau linguri-biberon), C. Virag menţionează existenţa şi a altor descoperiri, pe care le consideră asemănătoare cu vasul prezentat şi consemnează opinia potrivit căreia acestea au fost „puse pe seama influenţelor culturii Lengyel în România”" ${ }^{4}$. Încadrarea la care face trimitere autorul este considerată de S. Băcueţ-Crişan ca nefiind una pe deplin lămurită ${ }^{85}$.

Cele mai multe dintre descoperirile considerate de C. Virag ca fiind asemănătoare cu „vasul miniatural” cu tub de la Halmeu-Vamă (Iclod ${ }^{86}$, Suplacu de Barcău ${ }^{87}$, Tăşad ${ }^{88}$, Ciumeşti-La Silozuri / Fântâna Păşunii ${ }^{89}$, Pericei-Keller $\operatorname{tag}^{90}$ ) par a fi, cu excepţia recipientelor de la Ciumeşti, căuşe de linguri cu deschiderea largă a gurii, baza rotunjită şi tubul / mânerul găurit, poziţionat imediat sub buză. De altfel, cea mai mare parte a pieselor amintite au şi fost descrise ca reprezentând „linguri-biberon" ${ }^{\prime 1}$. Exceptând posibilele similarităţi de funcţionalitate, considerăm justificate opiniile potrivit cărora vasele cu tub şi aşa-numitele „linguri-biberon” sunt, în mod evident, diferite tipologic, constituind categorii ceramice distincte. Astfel, S. Băcueţ-Crişan considera că „lingurile-biberon se

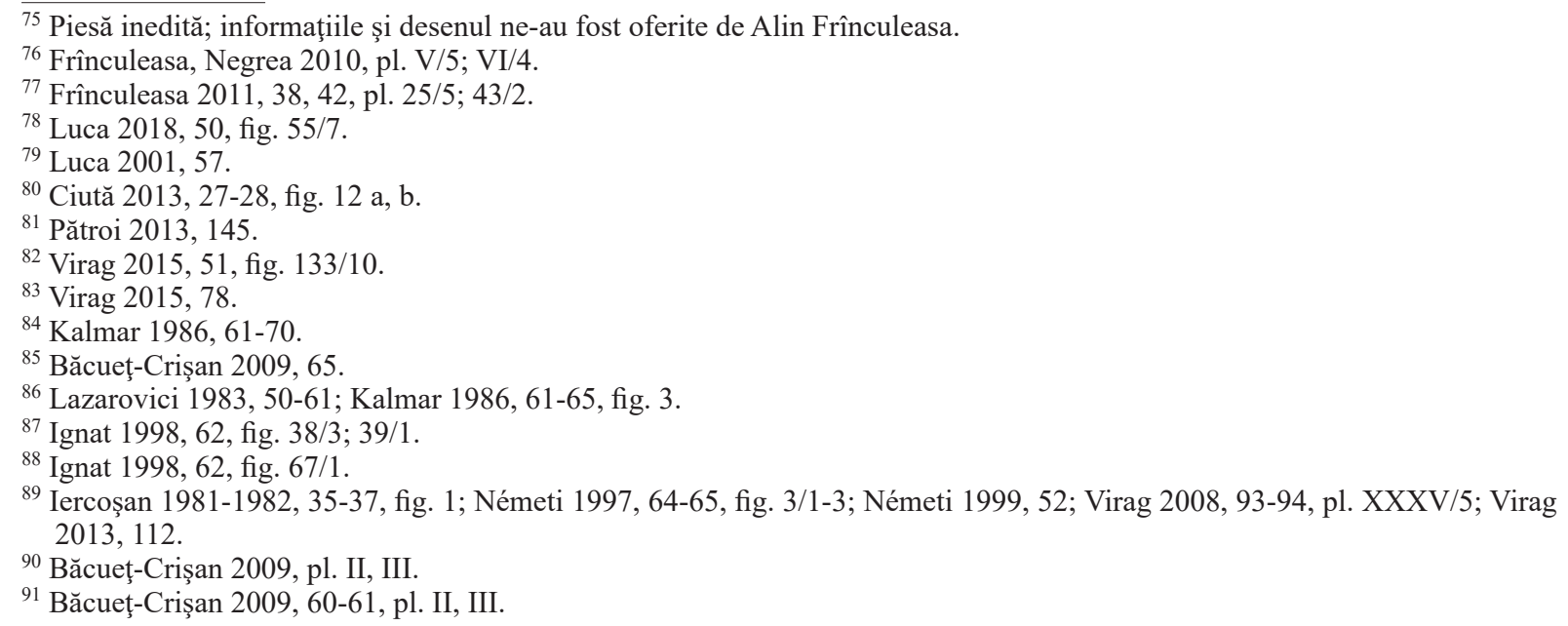


apropie tipologic mai mult de lingurile de lut, din care derivă probabil ca formă"92. Realitatea, susţinută de piesele descoperite, referitoare la existenţa, în acelaşi timp, a ligurilor-biberon şi a vaselor cu tub (chiar dacă acestea din urmă sunt semnificativ mai reduse numeric), poate constitui un alt argument în favoarea tratării distincte a celor două tipuri ceramice.

În situl de la Urziceni-Vamă (jud. Satu Mare) a fost descoperit, în cursul campaniei din anul 2017, un vas cu tub ${ }^{93}$ depus într-un mormânt de înhumaţie (M. 86) atribuit culturii Bodrogkeresztúr ${ }^{94}$. În groapa mormântului au fost identificate rămăşiţele a doi defuncţi, un adult şi un copil, sugar. Dacă recipientele cu tub descoperite în mormintele adulților au fost considerate ,vase de libații”"95, asocierea dintre acestea și copii par să susțină utilizarea lor ca biberoane. Din analizele chimice efectuate pe vase asemănătoare, ca formă și capacitate de stocare, cu cele neo-eneolitice, dar descoperite în morminte de copii atribuite sfârșitului epocii bronzului (Augsburg-Haunstetten) şi începutului epocii fierului (Dietfurt-Tankstelle și Dietfurt-Tennisplatz), a rezultat că acestea fuseseră utilizate pentru stocarea laptelui de animale ${ }^{96}$.

În așezarea gumelnițeană de la Urlaţi (jud. Prahova) a fost identificat, în campania din 2014, un tub de vas, iar în cursul cercetării complexului nr. 3 (groapă) din anul 2018, a fost descoperit un fragment de vas cu tub (P1. IX/8)97.

Întrucât vasele cu tub descoperite la Pietroasa Mică-Gruiu Dării (jud. Buzău) au constituit deja subiectul unui studiu $^{98}$ dedicat exclusiv lor, vom prezenta descoperirile respective într-o manieră foarte succintă. Cele două vase au fost găsite întregi în zone situate în apropierea unor complexe arheologice, într-un context caracterizat prin amestecul de materiale eneolitice de tip Cernavoda I şi Cucuteni B.

Vasul descoperit în campania din anul $2013(\mathrm{Pl} . \mathrm{X} / 1-5)$ are dimensiuni reduse $(\mathrm{H}=5,1 \mathrm{~cm}$; Dmax. = 4,7 cm; Dgură $=3,4 \mathrm{~cm}$; Dfund = 3,3 cm; V = 20,5 ml) şi este singurul recipient cu două tuburi cunoscut, până acum, în aşezări atribuite eneoliticului de pe teritoriul României.

Cel de-al doilea vas (Pl. XI/1-7) a fost descoperit în anul 2018 şi are, asemănător cu primul, dimensiuni foarte reduse $(\mathrm{H}=4,6 \mathrm{~cm}$; Dmax. $=4,9 \mathrm{~cm} ;$ Dgură $=3,9 \mathrm{~cm} ; \mathrm{V}=24 \mathrm{ml})$. Particularitatea acestui recipient constă în decorul reprezentat de două proeminenţe conice, modelate în zona diametrului său maxim. Prezenţa acestor proeminenţe este importantă în contextul rarităţii decorurilor, de orice natură, identificate în cazul vaselor cu tub descoperite pe teritoriul ţării noastre.

Deși dimensiunile reduse ale recipientelor de la Gruiu Dării fac puțin plauzibilă utilizarea acestora ca biberoane, analizele chimice asupra conținutului unor vase cu tub având dimensiuni asemănătoare, dar atribuite unor perioade diferite (epoca bronzului și epoca fierului), au indicat stocarea laptelui de animale în recipientele respective ${ }^{99}$.

\section{Concluzii}

Stabilirea terminologiei folosite pentru denumirea tipului de vase care constituie tematica prezentului studiu s-a bazat, în principal, pe presupusa funcţionalitate a acestora. Încercările de determinare a utilităţii vaselor sunt, în mod evident, corelate cu demersurile întreprinse pentru atribuirea unei denumiri, cât mai adecvate, acestei categorii ceramice.

Apariția vaselor cu tub și, în special, a celor utilizate ca biberoane a fost corelată cu procesele de trecere a comunităţilor neolitice spre un mod de subzistență bazat pe cultivarea plantelor şi creşterea animalelor ${ }^{100}$. Astfel, s-a considerat că utilizarea pe scară largă a laptelui de origine animală pentru hrănirea copiilor a devenit posibilă doar odată cu extinderea procesului de domesticire al animalelor care îl produceau ${ }^{101}$.

Originea şi aria de răspândire a vaselor cu tub constituie, la fel ca și utilitatea acestora, subiectul unor opinii diverse. În ceea ce priveşte originea acestor vase, a fost formulată opinia potrivit căreia ea ar trebui ,căutată în Mediterana

\footnotetext{
$\overline{92}$ Băcueț-Crişan 2009, 62.

${ }^{93}$ Informaţie comunicată de C. Virag cu ocazia prezentării susţinute în cadrul Sesiunii Naţionale de Rapoarte Arheologice, desfăşurată la Cluj-Napoca, în anul 2018.

${ }^{94}$ Virag 2018, 147.

${ }^{95}$ Monah 1976, 274, nota 36.

${ }^{96}$ Dunne et al. 2019, 246-248

${ }^{97}$ Piese inedite; informaţiile şi desenul vasului descoperit în anul 2018 ne-au fost oferite de Alin Frînculeasa.

${ }^{98}$ Grigoraş 2018, 123-131, pl. I, II.

${ }^{99}$ Dunne et al. 2019, 247.

${ }^{100}$ Dunne et al. 2019, 246; Halcrow 2019, 182.

${ }^{101}$ Howcroft, Eriksson, Lidén 2012, 31.
} 
orientală" ${ }^{102}$. Astfel, s-a constatat că vasele cu tub apar „încă din cele mai vechi nivele neolitice de la Susa şi din Mesopotamia”, fiind descoperite în contexte diverse, „, atât în aşezări, cât şi în necropole”103. Recipientele cu tub au fost considerate ca având „o largă răspândire în timp şi spaţiu” ${ }^{04}$, vase aparţinând acestei categorii fiind cunoscute din descoperiri atribuite perioadei neo-eneolitice din Orient şi Europa.

Apariţia vaselor cu tub pe actualul teritoriu al României a fost plasată în contextul contactelor şi influenţelor manifestate în cadrul puternicelor legături existente între acest spaţiu şi „sud-estul Europei şi Asia Anterioară” ${ }^{105}$. Am menţionat deja în cuprinsul acestui studiu şi opiniile divergente referitoare la atribuirea unora dintre vasele cu tub descoperite în zona de nord-vest a țării noastre influenţelor culturii Lengyel ${ }^{106}$.

Harta (Pl. XII) cu localizarea descoperirilor de vase cu tub identificate pe actualul teritoriu al României indică prezenţa acestora pe o suprafaţă extinsă, în cadrul unor aşezări şi doar într-un singur caz într-o necropolă, aparţinând mai multor culturi neo-eneolitice. Centralizarea şi gruparea acestor descoperiri în funcţie de culturile arheologice cărora le sunt atribuite, indică o clară preponderenţă a prezenţei lor în situri aparţinând perioadei eneolitice şi, mai cu seamă, eneoliticului final. Această constatare ar putea fi corelată cu evoluția și extinderea activităților de cultivare a plantelor, precum și cu generalizarea creșterii animalelor domestice.

Opiniile referitoare la ,înrudirea” dintre vasele cu tub şi cele cu „cioc” / ,jgheab” sau lingurile-biberon, precum şi cele legate de posibilele „,filiaţii” existente între acestea au fost deja analizate în cuprinsul acestui studiu. În această privinţă, putem concluziona, bazându-ne pe centralizarea descoperirilor existente şi prezentate în ilustraţii, că posibilele similitudini de utilizare ale acestor tipuri de recipiente nu sunt suficiente pentru argumentarea includerii acestora, fără nici o distincţie, într-o singură categorie tipologică. Zona de dispunere a tubului (imediat sub buza căușului, la linguri și, predominant, în zona mediană a corpului, la vase) şi diferenţele evidente, de formă, dintre tub şi „,cioc”, precum şi dintre corpul / recipientul de stocare al vaselor cu tub şi cel al lingurilor-biberon, conduc spre includerea acestora în categorii ceramice distincte. De asemenea, descoperirea în acelaşi timp şi spaţiu, a unor vase aparţinând celor trei tipuri ceramice menţionate, constituie un alt argument pentru încadrarea lor în categorii tipologice diferite. Acelaşi argument poate fi invocat şi pentru reevaluarea opiniilor referitoare la „derivarea" vaselor cu tub din cele cu ,cioc” sau din lingurile-biberon.

Considerăm că includerea recipientelor cu tub în categoria, mai largă, a vaselor pseudo-kernos ${ }^{107}$ sau ,zise kernoi"108 necesită clarificări suplimentare. Definirea categoriei pseudo-kernos ca reprezentând, în general, recipiente „compuse” al căror corp principal / vas-suport nu comunică cu formele ataşate ${ }^{109}$, credem că exclude posibilele asemănări de utilizare dintre acestea şi vasele cu tub. Chiar şi acceptarea includerii vaselor cu tub în categoria recipientelor pseudo-kernos, doar pe baza simplei asemănări formale dintre acestea necesită, în opinia noastră, o evaluare mult mai nuanţată. Analiza caracteristicilor acestor vase relevă evidentele diferenţe tipologice, morfologice şi decorative existente între recipientele amintite. Categoria pseudo-kernos cuprinde recipiente (de obicei „,compuse”) mult mai elaborate din punct de vedere al formelor şi manierei de modelare, calitatea bună sau foarte bună a pastei şi complexitatea decorurilor aplicate constituind caracteristici care le conferă atribute mult mai pregnant „,ceremoniale” decât cele ale vaselor cu tub. Pasta, în general cu incluziuni, raritatea decorurilor şi maniera destul de puţin îngrijită de realizare a vaselor cu tub conferă acestora aspectul unor recipiente cu caracteristici de uz comun. Chiar şi aşa, o parte dintre cercetători au atribuit unora dintre aceste recipiente conotaţii cultice în strânsă legătură cu comportamente ce ţin de spiritualitatea perioadei respective. Această abordare a fost determinată de relativa raritate a pieselor de acest tip, de dificultăţile de identificare a utilităţii unor vase cu dimensiuni miniaturale, precum şi de prezenţa, chiar dacă extrem de rară, a unora dintre acestea în contexte cu valenţe de sacralitate. În ceea ce priveşte frecvența redusă a descoperirilor, considerăm că această constatare trebuie analizată avându-se în vedere descoperirile centralizate în acest studiu, foarte probabila existenţă a unor vase asemănătoare, încă nepublicate (vezi piesele inedite de la Mălăieştii de Jos, Urlaţi şi Urziceni-Vamă, menţionate în acest articol) sau publicate, dar rămase neidentificate datorită încadrării neexplicite sau includerii acestora în categorii ceramice mai largi ori tipologii diverse. Referitor la vasele cu tub miniaturale, aparent fără o utilitate practică şi poate tocmai de aceea „atractive” în a fi asociate unor comportamente cultice, au fost formulate câteva opinii, amintite şi în acest studiu, privind posibilele funcţionalităţi ,,profane” ale acestora: picurarea sau întinderea culorilor pe ceramică / suprafeţe diverse, dozarea administrării de substanţe analgezice / curative ş.a. Existenţa unei singure informaţii

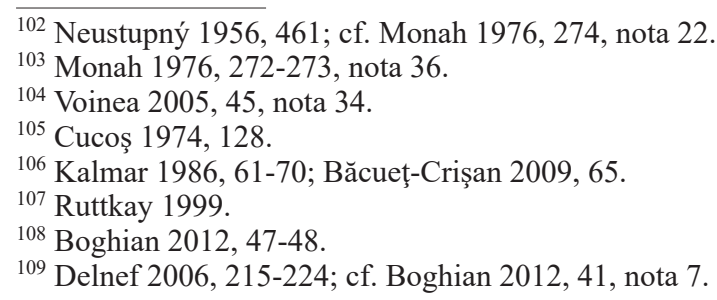


referitoare la descoperirea pe teritoriul României a unui vas cu tub identificat într-un mormânt de înhumaţie ${ }^{110}$ nu permite decât formularea unor vagi supoziții referitoare la caracterul acestei depuneri. Având în vedere faptul că în mormântul respectiv au fost identificate rămăşiţele unui copil, sugar ${ }^{111}$, se poate doar presupune faptul că vasul cu tub ar fi putut fi depus ca accesoriu / paraphernalia în cadrul ceremonialului funerar.

Apreciem că, mai ales pentru o perioadă care ţine de preistorie, toate opiniile referitoare la posibilele funcţionalităţi, practice, rituale sau poate combinate, ale vaselor cu tub, trebuie luate în considerare şi supuse unor analize bazate pe criterii obiective. Referitor la valenţele rituale atribuite unora dintre aceste piese, ne-am exprimat opinia potrivit căreia ar fi necesară reevaluarea părerilor care stabilesc un determinism, direct şi neechivoc, între contextul descoperirilor şi funcţionalitatea vaselor identificate ${ }^{112}$. În ceea ce priveşte stabilirea funcţionalităţilor practice, este foarte probabil ca cel puţin o parte dintre vasele cu tub, ca de altfel şi alte recipiente aparţinând ceramicii neoeneolitice, să fi avut utilităţi multiple, distincte şi diferite de scopul iniţial pentru care fuseseră realizate. Din acest motiv, rezultatele analizelor chimice realizate pentru determinarea conţinutului vaselor cu tub, ar putea reprezenta doar o etapă de moment din posibilul spectru de funcţionalităţi ale acestora.

Există numeroase vase cu tub, în special cele descoperite în cursul unor campanii mai vechi, pentru care nu a fost precizat contextul arheologic al descoperirii. În cazul vaselor pentru care această informaţie a fost consemnată se poate constata faptul că majoritatea provin din depuneri situate în afara complexelor, din stratul de cultură, foarte puţine din locuinţe şi gropi, doar un singur vas fiind descoperit într-un mormânt. Astfel, s-ar putea afirma că majoritatea covârşitoare a vaselor cu tub descoperite până acum provin din aşa-zise contexte ,profane” sau „casnice”, constatare care pare a fi în contradicţie cu opiniile referitoare la valenţele cultice ale acestora. Referitor la acest aspect, ne-am exprimat deja opinia potrivit căreia contextul arheologic al descoperirilor nu constituie un criteriu definitoriu pentru stabilirea caracterului sacru, profan sau combinat al acestor vase.

Am preluat şi menţionat, în toate cazurile în care au fost consemnate, informaţiile referitoare la dimensiunile / capacitatea de stocare a vaselor cu tub descoperite, considerând ca fiind pe deplin justificate opiniile potrivit cărora aceste date sunt extrem de relevante pentru stabilirea posibilelor utilităţi ale recipientelor respective. În acelaşi scop, am acordat o atenţie specială consemnării tuturor descrierilor cu informaţii referitoare la prezenţa sau nu a urmelor de ardere / culoare, poziţia, forma şi dimensiunile tubului de scurgere.

În final, reiterăm opinia, argumentată în cuprinsul acestui articol, potrivit căreia am considerat denumirea de vase cu $t u b$ ca fiind cea mai adecvată pentru desemnarea categoriei tipologice în care ar trebui încadrate aceste recipiente. Considerăm că denumirea acestei categorii poate fi individualizată, fără echivoc, doar pe baza criteriului obiectiv al principalei şi inconfundabilei caracteristici tipologice a acestor vase (prezența tubului / tuburilor) şi nicidecum pe varietatea, de cele mai multe ori intuitiv determinată, a numeroaselor funcţionalităţi prezumate.

Sperăm că acest studiu va contribui la identificarea mult mai multor piese asemănătoare, imprecis ori neclar încadrate sau rămase, deocamdată, nepublicate şi va asigura premisele analizării mult mai unitare a acestor materiale ceramice ,speciale”.

\section{Mulțumiri}

Colegilor Alin Frînculeasa (Muzeul de Istorie şi Arheologie Prahova) pentru amabilitatea de a ne pune la dispoziţie informații, fotografii și desene ale unor piese inedite; Cristian Virag (Muzeul Judeţean Satu Mare), Marius Ciută (Inspectoratul de Poliție al Județului Alba) şi Cristian Eduard Ştefan (Institutul de Arheologie „Vasile Pârvan” București) pentru promptitudinea cu care ne-au oferit surse bibliografice şi sugestii extrem de utile pentru realizarea acestui studiu; Lăcrămioara-Elena Istina (Complexul Muzeal „Iulian Antonescu” Bacău) pentru fotografierea vasului cu tub descoperit la Vermeşti-Cetăţuie; Stănică Pandrea (Muzeul Brăilei „Carol I”) pentru acceptul de a realiza şi utiliza imagini ale vasului cu tub din colecţia muzeului; Daniel Garvăn (Muzeul Judeţean Buzău) pentru fotografierea vasului de la Rîmnicelu şi Cătălin Dinu (Muzeul Județean Buzău) pentru sprijinul acordat în traducerea rezumatului şi a legendelor ilustraţiilor aferente prezentului studiu.

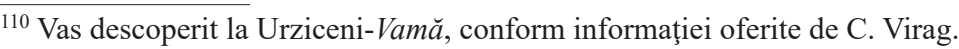

${ }^{111}$ Virag et al. 2017, 147, 396, fig. 2.

${ }^{112}$ Grigoraş 2018, 125-126.
} 


\section{BIBLIOGRAFIE}

Anastasiu, Harţuche 1967

Andreescu 2002

Băcueţ-Crişan 2009

Boghian 2012

Boghian, Mihai 1987

Bókay 1937

Bologa 1960

Ciută 2013

Contenau 1927

Crişan 1968

Cucoş 1974

Delnef 2006

Dumitrescu 1950

Dumitrescu 1963

Dumitroaia 1992

Dunne et al. 2019

Frînculeasa, Negrea 2010

Frînculeasa 2011

Grigoraş 2018

Halcrow 2019

Harţuche 1976

Howcroft, Eriksson, Lidén 2012

Iercoşan 1981-1982

Ignat 1998
Anastasiu, F., Harţuche, N., Cercetări şi descoperiri arheologice în raionul Brăila, Danubius, I, 1967, 19-39.

Andreescu, R.-R., Plastica antropomorfă gumelniţeană. Analiză primară, Monografii, III, Bucureşti, 2002.

Băcueț-Crișan, S., Consideraţii privind lingurile-biberon neolitice, Annales Universitatis Apulensis. Series Historica, 13, 2009, 59-68.

Boghian, D., Unele observaţii cu privire la vasele cucuteniene de tip kernos / pseudo kernos, Mem.Antiq., XXVIII, 2012, 39-63.

Boghian, D., Mihai, C., Le complexe de culte et le vase à décor ornithomorphe peint découverts à Buznea (dép. de Iaşi), în M. Petrescu-Dîmboviţa, N. Ursulescu, D. Monah, V. Chirica (eds.), La civilisation de Cucuteni en contexte européen, Session scientifique dédiée au centenaire des premières découvertes de Cucuteni (Iaşi - Piatra Neamt,, 24-28 septembre 1984), Bibliotheca Archaeologica Iassiensis I, Iaşi, 1987, 313-324.

Bókay, J., Jahresbericht für Kinderheilkunde, Berlin, 1937.

Bologa, V., ,, Gutti” (biberoane) romane din sticlă, în M. Macrea (ed.) Omagiu lui Constantin Daicoviciu cu prilejul implinirii a 60 de ani, Editura Academiei R.P.R., Bucureşti, 1960, 55-58.

Ciută, M. M., O locuinţă vinčiană timpurie descoperită la Limba-Oarda de Jos Şesu Orzii (jud. Alba), Apulum, L, 2013, 23-45.

Contenau, G., Manuel d'archéologie orientale, 1, Paris, 1927.

Crişan, E., Un biberon hallstattian, $A M N$, V, 1968, 405-407.

Cucoş, Șt., Vase neolitice cu tub şi semnificaţia lor, SCIV, 25, 1, 1974, 125-130.

Delnef, H., Kernos et pseudo-kernos au Britzgyberg (Illfurth, dép. Haut-Rhin), ArchKorresp, Jahrgang, 36, Heft 2, 2006, 215-224.

Dumitrescu, H., Cercetări arheologice la Văleni (jud. Neamţ), SCIV, I, 2, 1950, 19-51.

Dumitrescu, Vl., Originea şi evoluţia culturii Cucuteni-Tripolie (I), SCIV, XIV, $1,1963,51-78$.

Dumitroaia, Gh., Materiale şi cercetări arheologice din nord-estul judeţului Neamţ, Mem.Antiq., XVIII, 1992, 63-145.

Dunne, J., Rebay-Salisbury, K., Salisbury, R. B., Frisch, A., Walton-Doyle, C., Evershed, R. P., Milk of ruminants in ceramic baby bottles from prehistoric childs graves, Nature, 574, 2019, 246-248.

Frînculeasa, A., Negrea, O., Un sit din epoca neo-eneolitică în zona colinară a Munteniei - Seciu, jud. Prahova, Buletinul Muzeului Judeţean Teleorman, Seria Arheologie, 2, 2010, 123-138.

Frînculeasa, A., Seciu - judeţul Prahova. Un sit din epoca neo-eneolitică în nordul Munteniei, Editura Oscar Print, Bucureşti, 2011.

Grigoraş, L., Vase eneolitice cu tub descoperite la Pietroasa Mică-Gruiu Dării (com. Pietroasele, jud. Buzău), Mousaios, XXII, 2018, 123-131

Halcrow, S. E., Early Europeans bottle-fed babies with animal milk, Nature, 574, 2019, 182-183.

Harţuche, N., Vasul-biberon eneolitic de la Râmnicelu (jud. Brăila), Mem.Antiq., IV-V (1972-1973), 1976, 265-267.

Howcroft, R., Eriksson, G., Lidén, K., The Milky Way: the implications of using animal milk product in infant feeding, Anthropozoologica, 47, 2012, 31-43.

Iercoşan, N., Un vas-biberon eneolitic descoperit la Ciumeşti, Satu Mare. Studii și Comunicări, V-VI, 1981-1982, 35-38.

Ignat, D. F., Grupul cultural neolitic Suplacu de Barcău, în Bibliotheca Historica et Archaeologica Banatica, XVI, Editura Mirton, Timişoara, 1998. 
Jungsteinzeit 1981

Kalmar 1986

Kandyba 1937

Klebe, Schadewaldt 1955

Lazarovici, Németi 1983

Lips 1958

Luca 1984-1985

Luca 2001

Luca 2018

Mantu-Lazarovici 2004

Marinescu-Bîlcu 1971

Marinescu-Bîlcu 1972

Marinescu-Bîlcu 1974

Meller 2011

Monah 1976

Németi 1997

Németi 1999

Neustupný 1956

Niţu, Cucoş, Monah 1971

Paul 1992

Peiper 1966

Pătroi 2011

Roman 1971

Roska 1941

Roska 1943
Jungsteinzeit in Bulgarien (Neolithikum und Äneolithikum), coord. R. Busch, Komitee für Kultur der Volksrepublik Bulgarien, 1981.

Kalmar, Z., Elemente ale culturii Lengyel în nord-vestul României, $A M P, \mathrm{X}$, 1986, 61-70.

Kandyba, O., Schipenitz. Kunst und Geräte eines Neolithischen Dorfes, Bücher zur Ur- und Frühgeschichte, 6, Viena, 1937.

Klebe, D., Schadewaldt, H., Gefässe zur Kinderernährung im Wandel der Zeit, Frankfurt am Main, 1955.

Lazarovici, Gh., Németi, J., Neoliticul dezvoltat din nord-vestul României (Sălajul, Sătmarul şi Clujul), AMP, VII, 1983, 17-60.

Lips, I.E., Obîrşia lucrurilor. O istorie a culturii omenirii, Editura Științifică, Bucureşti, 1958.

Luca, G., Noi mărturii privind vasele cu tub de scurgere, Suceava, XI-XII, 19841985, 393-395.

Luca, S.A., Aşezări neolitice pe Valea Mureşului (II). Noi cercetări arheologice la Turdaş-Luncă. I. Campaniile anilor 1992-1995, Bibliotheca Musei Apulensis, XVII, Bucureşti, 2001.

Luca, S.A., Aşezări neolitice pe Valea Mureşului (III). Noi cercetări arheologice la Turdaş-Luncă. II. Campaniile anilor 1996-1998, în Bibliotheca Septemcastrensis, XXV, Editura Universităţii „Lucian Blaga”, Sibiu, 2018.

Mantu-Lazarovici, C.-M., Sanctuarele Precucuteni Cucuteni, ArhMold, XXV (2002), 2004, 47-67.

Marinescu-Bîlcu, S., Aspects tardifs de la civilisation à céramique rubanée et sa contribution à la génèse de la civilisation Précucuteni I, Prähistorische Zeitschrift, 46, 1, 1971, 4-36.

Marinescu-Bîlcu, S., Quelques aspects du problème de l'apport de la céramique rubanée à la formation de la civilisation Précucuteni I, Alba Regia, XII (1971), 1972, 162-171.

Marinescu-Bîlcu, S., Cultura Precucuteni pe teritoriul României, Biblioteca de Arheologie, XXII, Editura Academiei R.S.R., Bucureşti, 1974.

Meller, H. E., Bronzerausch: Spätneolithikum und Frühbronzezeit, Begleithefte zur Dauerausstellung im Landesmuseum für Vorgeschichte Halle, 4, Halle, 2011.

Monah, D., Câteva observaţii asupra vaselor neo-eneolitice cu tub de scurgere, Mem.Antiq., IV-V (1972-1973), 1976, 269-275.

Németi, J., Câteva consideraţii asupra colecţiei „Kovács”, Satu Mare. Studii şi Comunicări, Seria Arheologie, XIV, 1997, 63-68.

Németi, J., Repertoriul arheologic al zonei Careiului, Bibliotheca Thracologica, XXVIII: Bucureşti, 1999.

Neustupný, C., K relativni chronologii volutové keramiky, Archeologické rozhledy, VIII, 1956, 386-407.

Niţu, A., Cucoş, Șt., Monah, D., Ghelăieşti (Piatra Neamţ) I. Săpăturile din 1969 în aşezarea cucuteniană „Nedeia”, Mem.Antiq., III, 1971, 11-64.

Paul, I., Cultura Petreşti, Monografii - Repertorii, Editura Museion: Bucureşti, 1992.

Peiper, A., Chronik der Kinderheilkunde, Leipzig, 1966.

Pătroi, C.N., Caracterul gumelniţean al culturii eneolitice Sălcuţa, Buletinul Muzeului Județean Teleorman, Seria Arheologie, 3, 2011, 143-154.

Roman, P., Strukturänderungen des Endäneolithikums im Donau-KarpatenRaum, Dacia N.S., XV, 1971, 31-169.

Roska, M., Die Sammlung Zsofia von Torma in der Numismatisch-Archäologischen Abteilung des Siebenbürgischen Nationalmuseums, Editura Minerva, Cluj, 1941.

Roska, M., Az Erdély öskori festett agyagmüvesség, Közlemények, III, 1, 1943, 61-80. 
Ruttkay 1999

Sălceanu 2008

Sîrbu et al. 2011

Tichý 1956

Virag 2008

Virag 2013

Virag 2015

Virag et al. 2018

Voinea 2005
Ruttkay, E., Boleraz-Gruppe, în E. Lenneis, C. Neugebauer-Maresh, E. Ruttkay (eds.), Jungsteinzeit im Osten Österreichs, Verlag Niederösterreichisches Pressehaus, St. Polten - Wien, 1999.

Sălceanu, I., Orizontul Sălcuţa IV - Herculane II-III în vestul României, Seria Monographia, I, Editura Solstițiu, Satu Mare, 2008.

Sîrbu, V., Matei, S., Costache, D., Grigoraş, L., El Susi, G., Pietroasa MicăGruiu Dării, jud. Buzău. Descoperirile din epocile neolitică şi a bronzului (III), in Monografii Arheologice, III, Biblioteca Mousaios, Brăila - Buzău, 2011.

Tichý, R., Habitat néolithique de Mahelnice en Moravie, Archeologické rozhledy, VIII, 1956, 3-8.

Virag, C., A Kovács gyüjtemeny ujkökory es rezkori keramiaanyaga, A Nyiregyhazi Josa Andras Muzeum Evkonyve, L, 2008, 91-159.

Virag, C., Materiale ceramice eneolitice din colecţia Kovács, Satu Mare. Studii şi Comunicări, XXIX/1, 2013, 111-128.

Virag, C., Situl neolitic Halmeu-Vamă, Editura Muzeului Sătmărean, Satu Mare, 2015.

Virag, C., Astaloş, C. T., Gyurka, O., Tentiş, D. M., Brânduşan, L., Urziceni, com. Urziceni, jud. Satu Mare, Urziceni-Vade Ret, Punct: Vamă, CCA. Campania 2017, 2018, 147, 148.

Voinea, V. M., Ceramica complexului cultural Gumelniţa-Karanovo VI. Fazele A1 şi A2, Editura Ex Ponto, Constanţa, 2005.

\section{LIST OF ILLUSTRATIONS}

Plate I. 1-6. Vessel with tube discovered at Rîmnicelu: 1-4. after Anastasiu, Harţuche, 1967, fig. 10. 3, 3a; Harţuche, 1976, 396, fig. 1, without scale; 5, 6. photo: D. Garvăn.

Plate II. 1-5. Vessels with tube: 1-3. Stupini (after Crişan, 1968, fig. 1, 2, without scale); 4. Pecica-Şanţul Mare (after Roman, 1971, abb. 37, 4, without scale); 5. Ostrovul Corbului (after Roman, 1971, abb. 6, 98, without scale); 6. Vessel with "beak": Băile Herculane-Peştera Hoţilor (after Roman, 1971, abb. 22, 24, without scale).

Plate III. 1-7. Vessels with tube: 1-4. Ghelăieşti-Nedeia (after Cucoş, 1974, fig. 1; 2/1, without scale); 5-7. Tîrpeşti (after Marinescu-Bîlcu, 1971, fig. 1/11, without scale).

Plate IV. 1-7. Vessel with tube discovered at Vermeşti-Cetăţuie: 1, 2. photo: L.-E. Istina; 3-7. after Monah, 1976, fig. $1 / 2 ; 5 / 4$ (without scale).

Plate V. 1-12. Potsherds with spout or "beak" discovered at Turdaş-Luncă (after Roska, 1941, pl. LXXVIII/9-16, without scale).

Plate VI. 1-6. Potsherds with tube or „beak”: 1-3. Ghelăieşti-Nedeia (after Monah, 1976, fig. 1/1; 5/2, 3, without scale); 4. Văleni - Piatra-Neamţ (after Dumitrescu, 1950, fig. 15/5, without scale); 5, 6. Ghigoeşti-Trudeşti (after Marinescu-Bîlcu, 1974, fig. 46/8 a, b).

Plate VII. 1-6. Vessels with tube: 1, 2. Ciumeşti-Gropi de silozuri (after Iercoşan, 1981-1982, fig. 1); 3. CiumeştiLa Silozuri / Fântâna Păşunii (after Nemeti, 1997, fig. 3/1); 4. Drăguşeni-Fălticeni (after Luca, 1984-1985, fig. 1, without scale); 5. Buznea-Silişte (after Boghian, Mihai, 1987, fig. 6/1); 6. Răuceşti-Munteni (after Dumitroaia, 1992, fig. 4/2).

Plate VIII. 1-6. Vessels with tube: 1. Păuca-Homm (after Paul, 1992, pl. XXIII/4); 2. Ghirbom (after Paul, pl. XXVI/5); 3. Lişcoteanca (after Voinea, 2005, pl. 45/1, without scale); 4. Drama (after Voinea, 2005, pl. 45/2, without scale); 5. Cuneşti (after Voinea, 2005, pl. 45/3, without scale); 6. Căscioarele (after Voinea, 2005, pl. 89/3).

Plate IX. 1-8. Vessels with tube: 1. Mălăieştii de Jos (drawing: A. Frînculeasa); 2, 3. Seciu-La Pompieri (after Frînculeasa, Negrea, 2010, pl. V/5; VI/4); 4, 5. Limba-Oarda de Jos - Şesu Orzii (after Ciută, 2013, fig. 12 a, b); 6, 7. Halmeu-Vamă (after Virag, 2015, fig. 133/10); 8. Urlaţi (drawing: A. Frînculeasa).

Plate X. 1-5. Vessel with two tubes discovered at Pietroasa Mică-Gruiu Dării (after Grigoraş, 2018, pl. I). 
Plate XI. 1-7. Vessel with tube discovered at Pietroasa Mică-Gruiu Dării (after Grigoraş, 2018, pl. II).

Plate XII. Sites with artefacts considered by us as representing vessels with tube: 1. Pietroasa Mică-Gruiu Dării, Buzău County (two whole vessels); 2. Mălăieştii de Jos, Prahova County (vessel tube); 3. Seciu-La Pompieri, Prahova County (fragmentary vessel); 4. Urlaţi, Prahova County (vessel tube and a fragment of vessel with tube); 5. Rîmnicelu, Brăila County (whole vessel); 6. Lişcoteanca, Brăila County (fragmentary vessel); 7. Cuneşti, Călărași County (fragment of vessel with tube); 8. Căscioarele, Călărași County (fragmentary vessel); 9. Drăgănești-Olt Corboaica, Olt County (fragment of vessel with tube); 10. Ostrovul Corbului, Mehedinți County (fragment of vessel with tube); 11. Almăjel, Mehedinți County (fragment of vessel with tube); 12. Vermeşti-Cetăţuie, Bacău County (whole vessel); 13. Ghelăieşti-Nedeia, Neamț County (whole vessel and a fragment of vessel tube); 14. Tîrpeşti, Neamț County (vessel tube); 15. Ghigoeşti-Trudeşti, Neamț County (vessel tube); 16. Văleni - Piatra-Neamţ, Neamţ County (fragment of vessel tube); 17. Răuceşti-Munteni, Neamț County (fragmentary vessel); 18. Traian-Dealul Viei, Neamț County (miniature vessel with tube); 19. Piatra Șoimului (formerly named Calu), Neamț County (fragment of vessel with tube); 20. Târgu Neamț-Dealul Pometea, Neamț County (fragment of vessel tube); 21. Buznea-Silişte, Iași County (fragmentary vessel); 22. Drăguşeni-Fălticeni, Suceava County (fragmentary vessel); 23. Păuca-Homm, Sibiu County (fragmentary vessel); 24. Ghirbom, Alba County (fragmentary vessel); 25. Limba-Oarda de Jos - Şesu Orzii, Alba County (fragment of vessel with tube); 26. Turdaş-Luncă, Hunedoara County (fragments of tubes and vessels with tube); 27. Pecica-Şanţul Mare, Arad County (fragment of vessel with tube); 28. Urziceni-Vamăa, Satu Mare County (reconstructable vessel); 29. Ciumeşti-Gropi de silozuri, Satu Mare County (whole vessel); 30. Ciumeşti- $L a$ Silozuri / Fântâna Păşunii, Satu Mare County (fragment of vessel with tube); 31. Halmeu-Vamă, Satu Mare County (fragmentary vessel).

\author{
LAURENŢIU GRIGORAŞ, \\ Muzeul Judeţean Buzău, \\ g_11973@yahoo.com
}




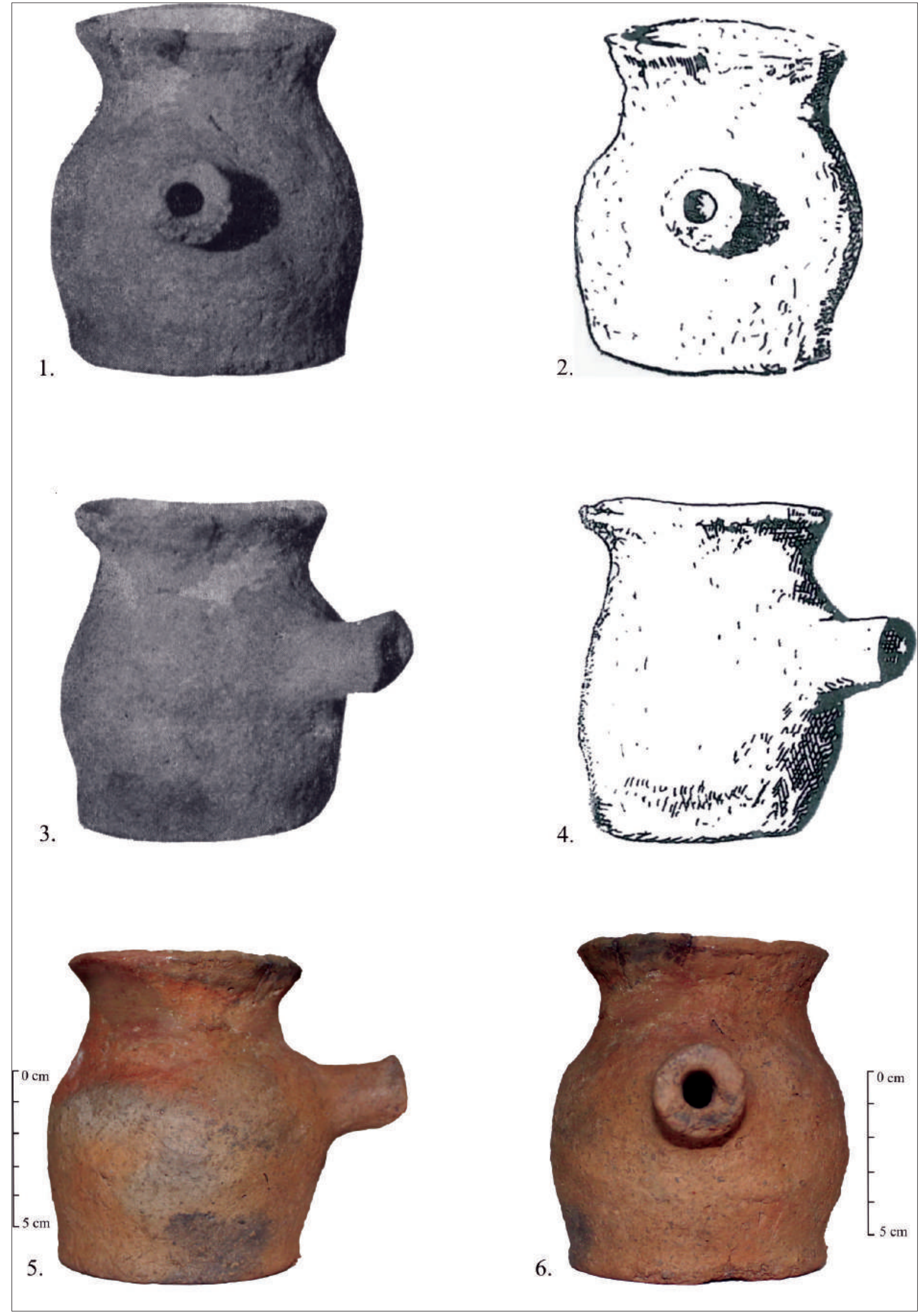

Planșa I. 1-6. Vas cu tub descoperit la Rîmnicelu: 1-4. după Anastasiu, Harţuche, 1967, fig. 10/3, 3a; Harţuche, 1976, 396, fig. 1, fără scară; 5,6 . foto: D. Garvăn. 

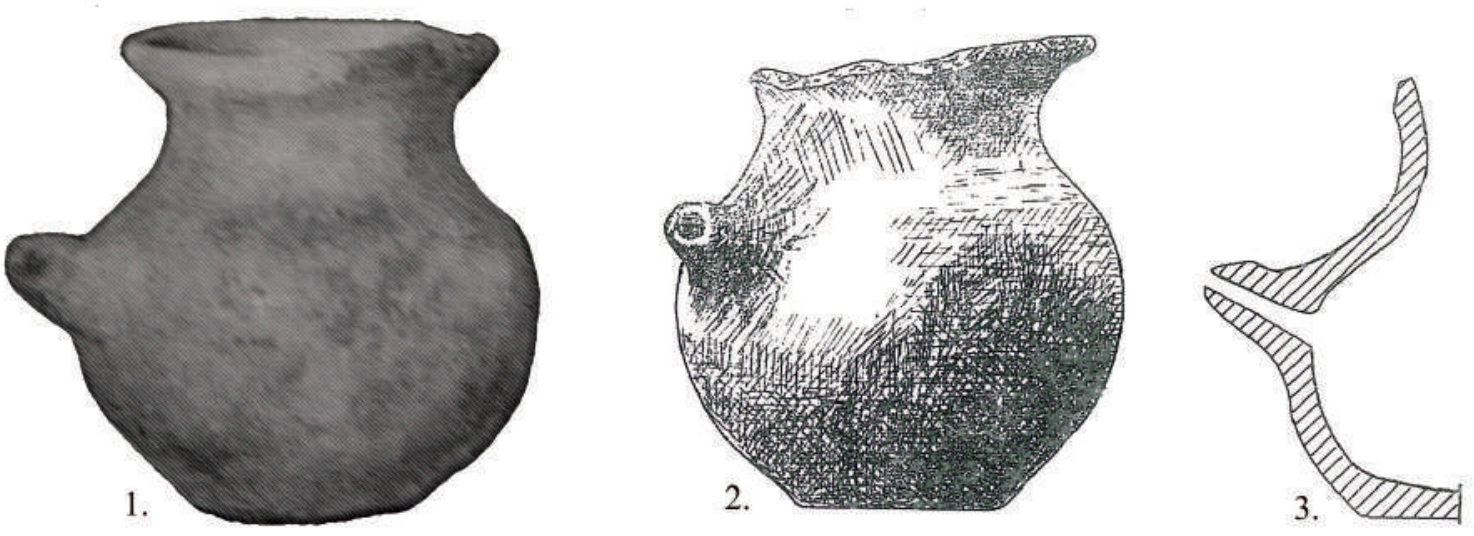

4.
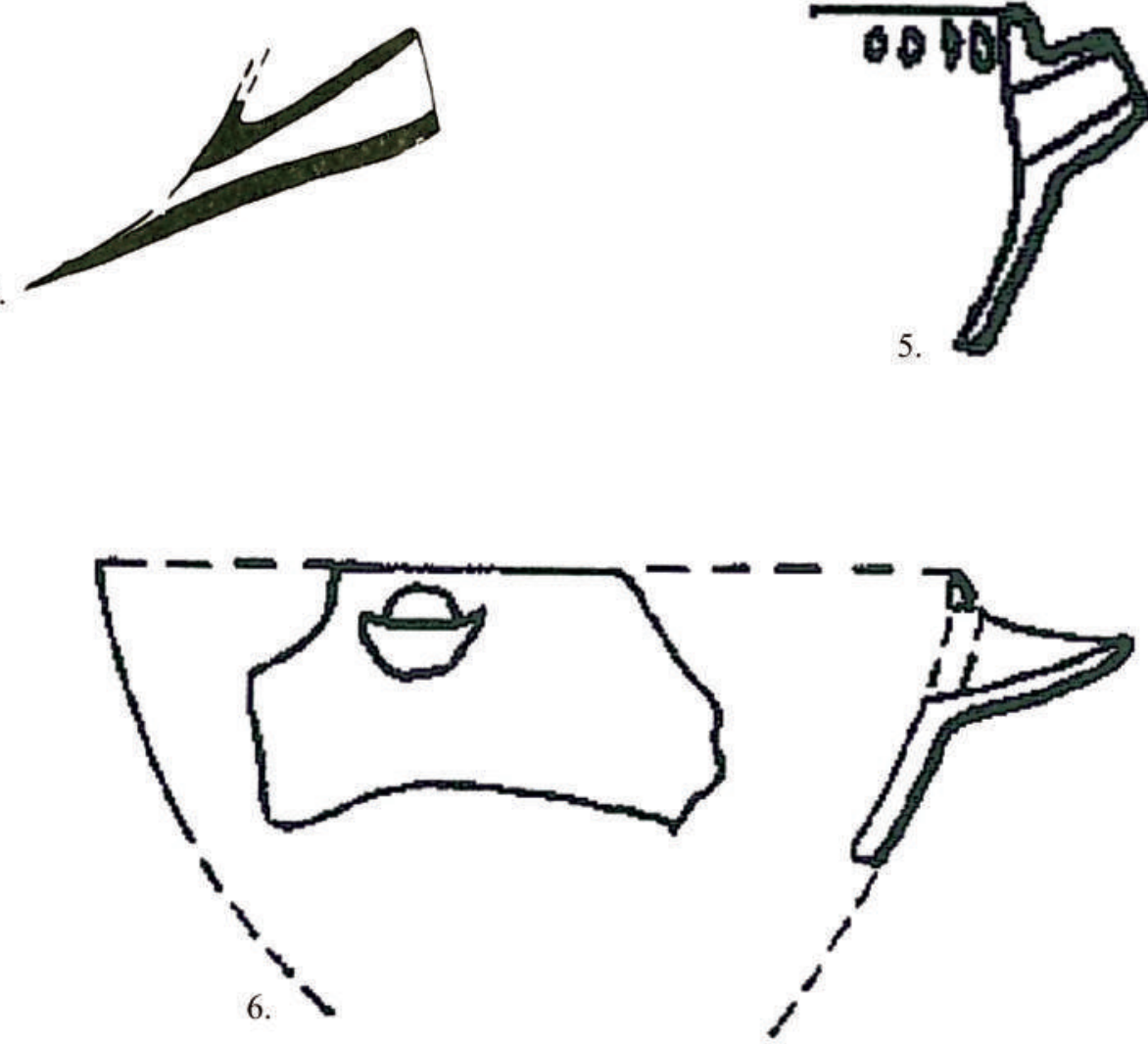

Planşa II. 1-5. Vase cu tub: 1-3. Stupini (după Crişan, 1968, fig. 1, 2, fără scară); 4. Pecica - Şanţul Mare (după Roman, 1971, abb. 37, 4, fără scară); 5. Ostrovul Corbului (după Roman, 1971, abb. 6, 98, fără scară); 6. Vas cu „,cioc”: Băile Herculane - Peştera Hoților (după Roman, 1971, abb. 22, 24, fără scară). 




Planșa III. 1-7. Vase cu tub: 1-4. Ghelăieşti - Nedeia (după Cucoş, 1974, fig. 1; 2/1, fără scară); 5-7. Tîrpești (după Marinescu-Bîlcu, 1971, fig. $1 / 11$, fără scară). 


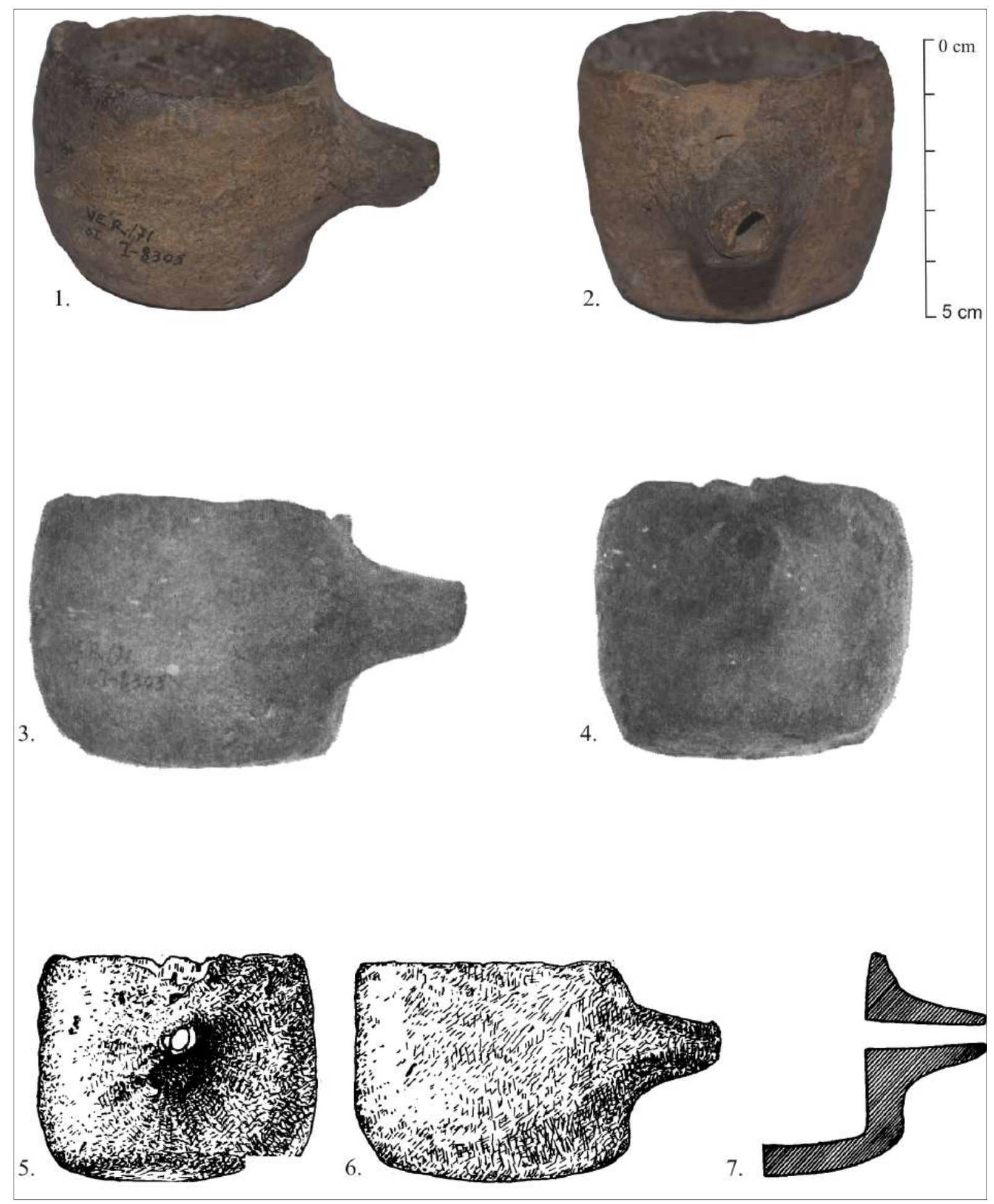

Planșa IV. 1-7. Vas cu tub descoperit la Vermești - Cetăţuie: 1, 2. foto: L.-E. Istina; 3-7. după Monah, 1976, fig. 1/2; 5/4 (fără scară). 


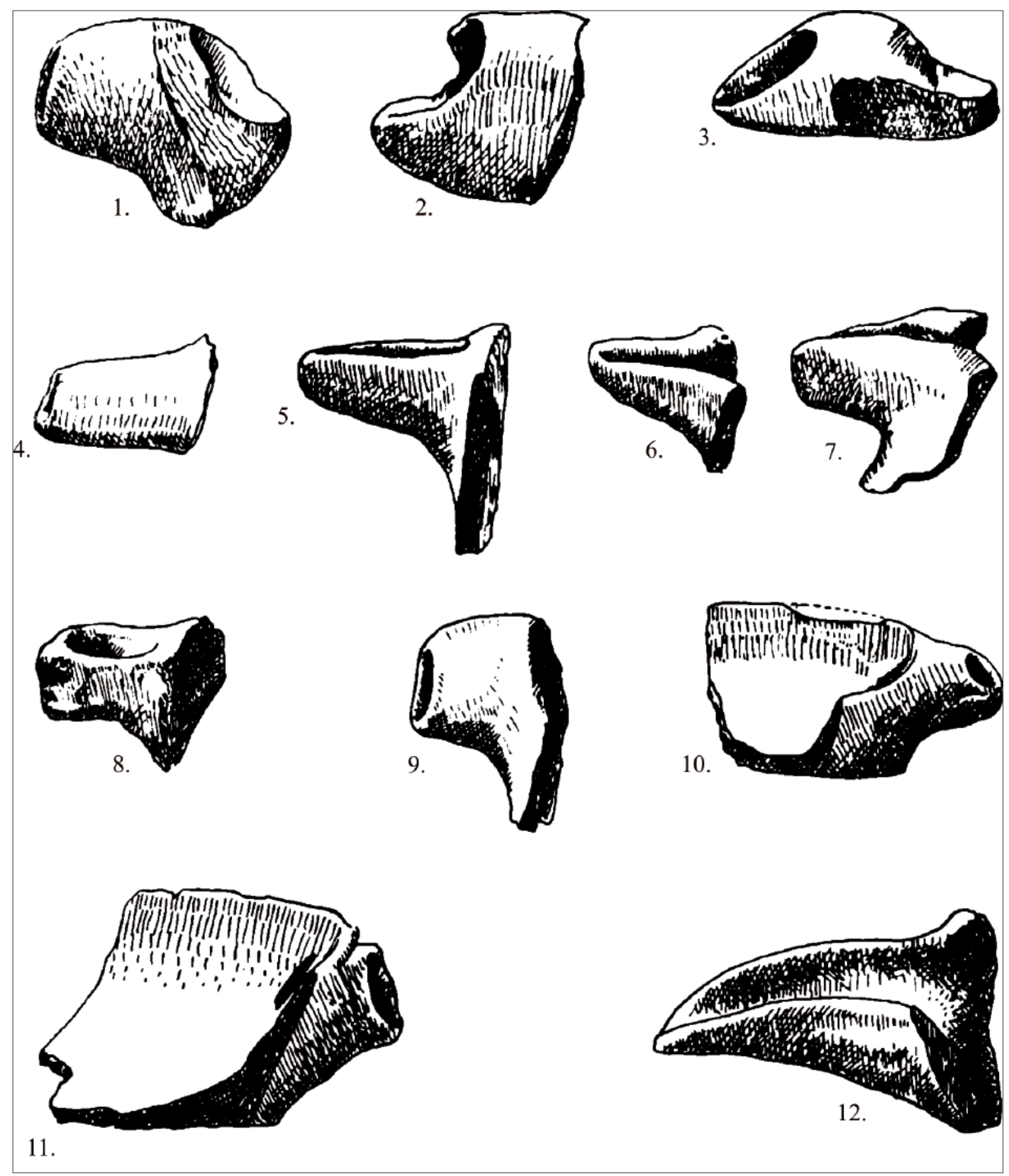

Planșa V. 1-12. Fragmente de vase cu tub sau ,,cioc” de scurgere descoperite la Turdaş - Luncă (după Roska, 1941, pl. LXXVIII/9-16, fără scară). 




Planșa VI. 1-6. Fragmente de vase cu tub sau „,ioc”: 1-3. Ghelăiești - Nedeia (după Monah, 1976, fig. 1/1; 5/2, 3, fără scară); 4. Văleni - Piatra-Neamţ (după Dumitrescu, 1950, fig. 15/5, fără scară); 5, 6. Ghigoeşti - Trudești (după Marinescu-Bîlcu, 1974, fig. 46/8 a, b). 



Planşa VII. 1-6. Vase cu tub: 1, 2. Ciumeşti - Gropi de silozuri (după Iercoşan, 1981-1982, fig. 1); 3. Ciumeşti - La Silozuri / Fântâna Păşunii (după Nemeti, 1997, fig. 3/1); 4. Drăguşeni - Fălticeni (după Luca, 1984-1985, fig. 1, fără scară); 5. Buznea - Silişste (după Boghian, Mihai, 1987, fig. 6/1); 6. Răuceşti - Munteni (după Dumitroaia, 1992, fig. 4/2). 




Planşa VIII. 1-6. Vase cu tub: 1. Păuca - Homm (după Paul, 1992, pl. XXIII/4); 2. Ghirbom (după Paul, pl. XXVI/5); 3. Lişcoteanca (după Voinea, 2005, pl. 45/1, fără scară); 4. Drama (după Voinea, 2005, pl. 45/2, fără scară); 5. Cuneşti (după Voinea, 2005, pl. 45/3, fără scară); 6. Căscioarele (după Voinea, 2005, pl. 89/3). 


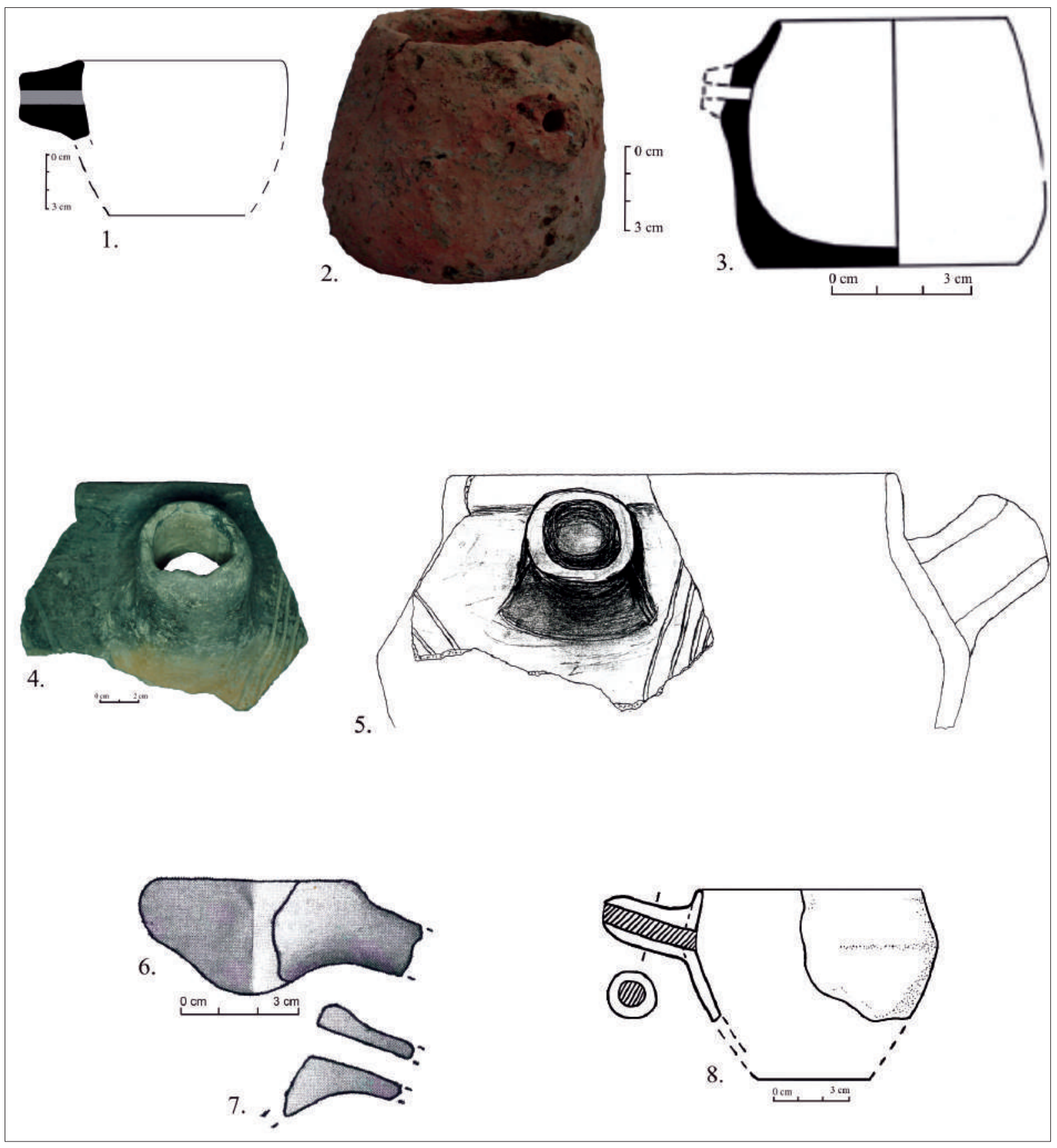

Planşa IX. 1-8.Vase cu tub: 1. Mălăieştii de Jos (desen: A. Frînculeasa); 2, 3. Seciu - La Pompieri (după Frînculeasa, Negrea, 2010, pl. V/5; VI/4); 4, 5. Limba - Oarda de Jos - Şesu Orzii (după Ciută, 2013, fig. 12 a, b); 6, 7. Halmeu - Vamă (după Virag, 2015, fig. 133/10); 8. Urlaţi (desen: A. Frînculeasa). 

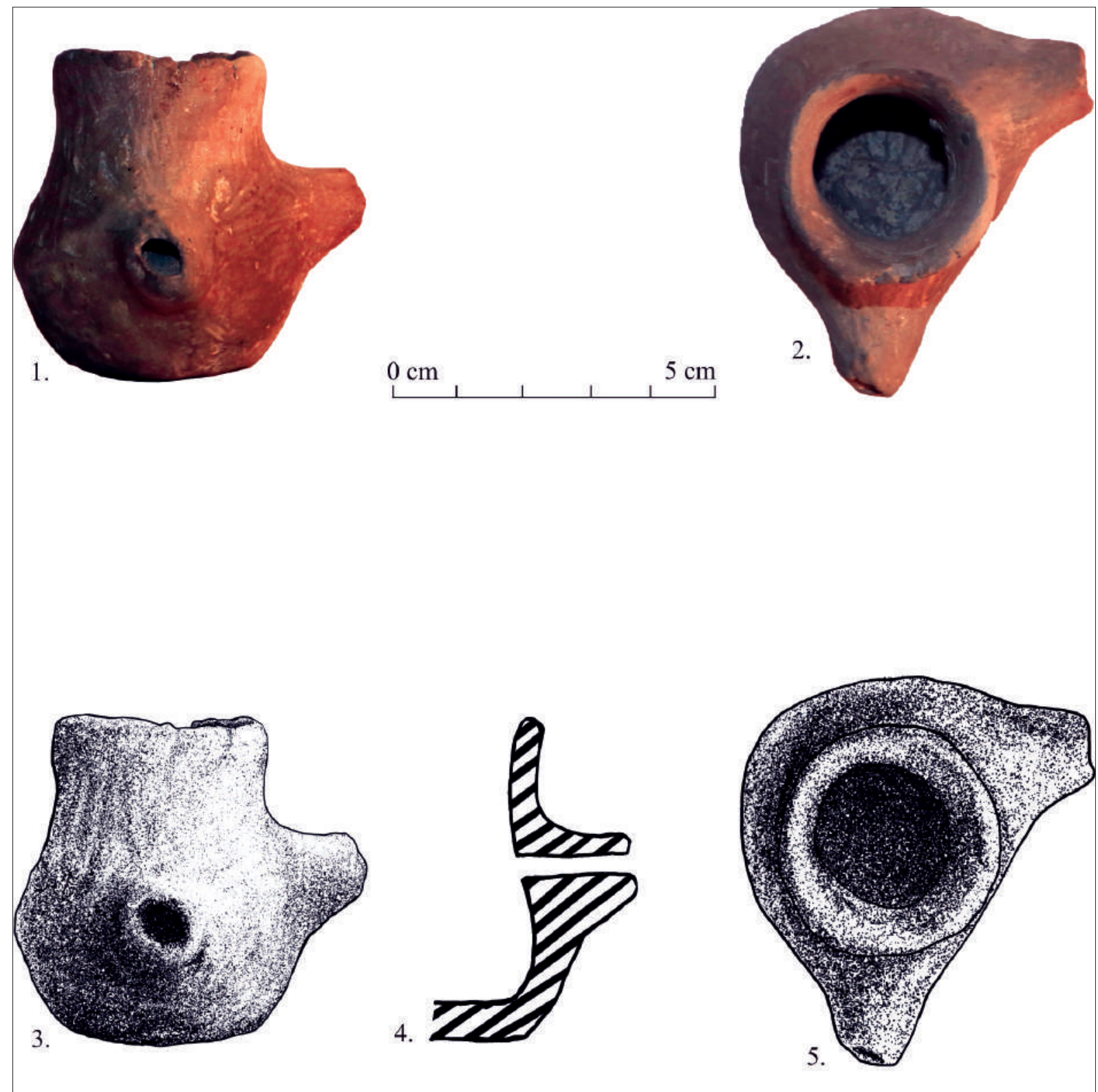

Planșa X. 1-5. Vas cu două tuburi descoperit la Pietroasa Mică - Gruiu Dării (după Grigoraş, 2018, pl. I). 


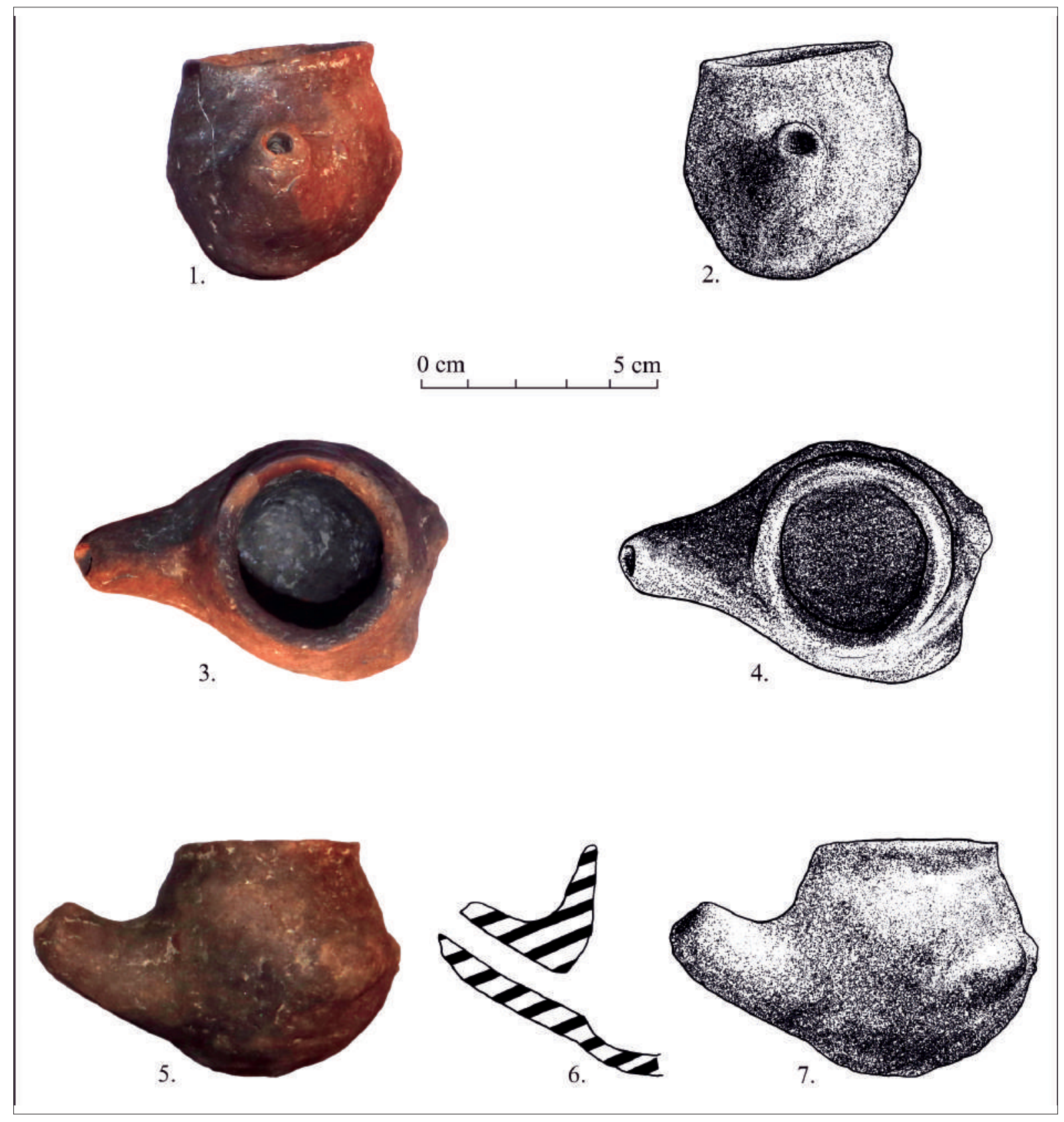

Planşa XI. 1-7. Vas cu tub descoperit la Pietroasa Mică - Gruiu Dării (după Grigoraş, 2018, pl. II). 


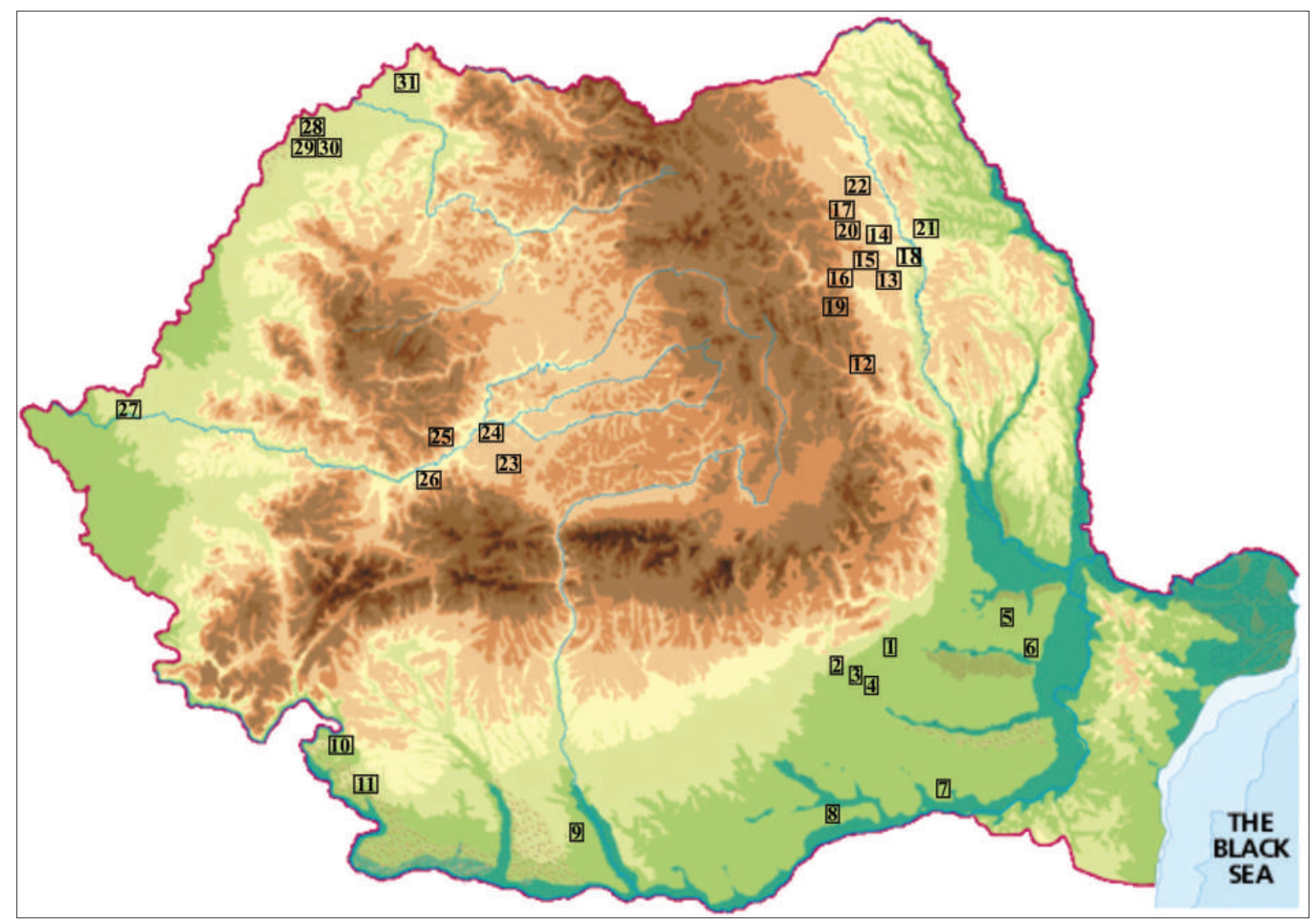

Planșa XII. Localizarea descoperirilor considerate de noi ca reprezentând vase cu tub: 1. Pietroasa Mică - Gruiu Dării, jud. Buzău (două vase întregi); 2. Mălăieştii de Jos, jud. Prahova (tub de vas); 3. Seciu - La Pompieri, jud. Prahova (vas fragmentar); 4. Urlaţi, jud. Prahova (tub de vas și fragment de vas cu tub); 5. Rîmnicelu, jud. Brăila (vas întreg); 6. Lişcoteanca, jud. Brăila (vas fragmentar); 7. Cunești, jud. Călăraşi (fragment de vas cu tub); 8. Căscioarele, jud. Călăraşi (vas fragmentar); 9. Drăgănești-Olt - Corboaica, jud. Olt (fragment de vas cu tub); 10. Ostrovul Corbului, jud. Mehedinţi (fragment de vas cu tub); 11. Almăjel, jud. Mehedinţi (fragment de vas cu tub); 12. Vermeşti - Cetăţuie, jud. Bacău (vas întreg); 13. Ghelăieşti - Nedeia, jud. Neamţ (un vas întreg şi un fragment dintr-un tub de vas); 14. Tîrpeşti, jud. Neamţ (tub de vas); 15. Ghigoeşti - Trudeş̧ti, jud. Neamţ (tub de vas); 16. Văleni Piatra-Neamţ, jud. Neamţ (fragment de tub de vas); 17. Răuceşti - Munteni, jud. Neamţ (vas fragmentar); 18. Traian - Dealul Viei, jud. Neamț (vas miniatural cu tub); 19. Piatra Șoimului (fost Calu), jud. Neamț (fragment de vas cu tub); 20. Târgu Neamț - Dealul Pometea, jud. Neamț (fragment de tub de vas); 21. Buznea - Silişte, jud. Iaşi (vas fragmentar); 22. Drăguşeni - Fălticeni, jud. Suceava (vas fragmentar); 23. Păuca - Homm, jud. Sibiu (vas fragmentar); 24. Ghirbom, jud. Alba (vas fragmentar); 25. Limba-Oarda de Jos - Şesu Orzii, jud. Alba (fragment de vas cu tub); 26. Turdaş - Luncă, jud. Hunedoara (fragmente de tuburi şi vase cu tub);

27. Pecica - Şanţul Mare, jud. Arad (fragment de vas cu tub); 28. Urziceni - Vamă, jud. Satu Mare (vas întregibil); 29. Ciumeşti Gropi de silozuri, jud. Satu Mare (vas întreg); 30. Ciumeşti - La Silozuri / Fântâna Păşunii, jud. Satu Mare (fragment de vas cu tub); 31. Halmeu - Vamă, jud. Satu Mare (vas fragmentar). 